OAK RIDGE NATIONAL LABORATORY

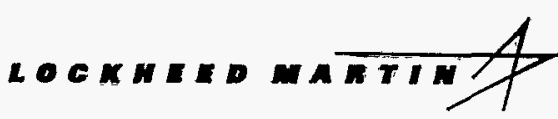

\section{Public Policy Responsibilities in a} Restructured Electric Industry: An Analysis of Values, Objectives, and Approaches

\author{
Bruce E. Tonn
}

Martin Schweitzer 
This report has been reproduced directly from the best available copy.

Available to DOE and DOE contractors from the Office of Scientific and Technical Information, P.O. Box 62, Oak Ridge, TN 37831; prices available from (423) 576-8401, FTS 626-8401.

Available to the public from the National Technical Information Service, U.S. Department of Commerce, 5285 Port Royal Rd., Springfield, VA 22161.

This report was prepared as an account of work sponsored by an agency of the United States Government. Neither the United States Government nor any agency thereof, nor any of their employees, makes any warranty, express or implied, or assumes any legal liability or responsibility for the accuracy, completeness, or usefulness of any information, apparatus, product, or process disclosed, or represents that its use would not intringe privately owned rights. Reference herein to any specific commercial product, process, or service by trade name, trademark, manufacturer, or otherwise, does not necessarily constitute or imply its endorsement, recommendation, or favoring by the United States Government or any agency thereof. The views and opinions of authors expressed herein do not necessarily state or reflect those of the United States Government or any agency thereof. 


\title{
PUBLIC POLICY RESPONSIBILITIES IN A RESTRUCTURED ELECTRIC INDUSTRY: AN ANALYSIS OF VALUES, OBJECTIVES, AND APPROACHES
}

\author{
Energy Division \\ Bruce E. Tonn \\ Martin Schweitzer
}

March 1996

\author{
Sponsored by \\ Competitive Resource Strategies Program \\ Office of Energy Efficiency and Renewable Energy \\ U.S. Department of Energy \\ Prepared by \\ OAK RIDGE NATIONAL LABORATORY \\ Oak Ridge, Tennessee 37831 \\ managed by \\ LOCKHEED MARTIN ENERGY RESEARCH CORPORATION \\ under contract No. DE-AC05-96OR22464 \\ for the \\ U.S. DEPARTMENT OF ENERGY
}





\section{EXECUTIVE SUMMARY}

Discussions and decisions in states as diverse as California, Wisconsin, and Rhode Island are focusing on moving the United States electric industry from one dominated by vertically-integrated and highly regulated utility-based electricity monopolies to one characterized by largely divested and independent generation, transmission, and distribution sectors and by vigorous wholesale and retail competition. Numerous issues must be solved for this transition to be successful. Three of the most important are how to deal with stranded investments, how to provide open access to transmission systems, and how to deal with potentially stranded benefits, which is the current term being used to describe environmental and social programs such as demandside management, low income programs, and renewable energy. This report explores how to meet public policy responsibilities, which are growing more acute, in a proactive fashion in a restructured United States electric industry.

The specific goals of this report are to (1) assess trade-offs in the short-term in meeting public policy responsibilities associated with stranded benefits and (2) introduce a series of new ideas that, if enacted, could substantially satisfy important public policy considerations. To guide these tasks, a three element framework of values, objectives, and broad actions was developed from a distillation and synthesis of ideas, arguments and stated principles found in the literature and various filings before state public utility commissions and discussed during three meetings organized by Oak Ridge National Laboratory on this topic. Table S1 presents the guiding values and objectives. Broad actions include demand-side management (DSM), research and development, portfolio/risk management, low income programs, and renewable energy. Other actions include a national wires charge, universal distribution charges, emissions caps, performance-based regulation, energy efficiency standards, regional transmission groups, and portfolio standards.

A fascinating characteristic of U.S. electric industry restructuring is that discussions, values, and transition plans widely differ across the states. Some states are moving aggressively toward full-retail competition and are being driven primarily by economic goals. Others are considering restructuring but are more influenced by other values, such as equity and environmental protection. And yet another group of states is only beginning to discuss restructuring. In all of these cases and more, state regulators and other people involved in the discussions face complex issues and difficult trade-offs.

To better understand what difficult trade-offs are facing the decision makers, this report explores key actions that would be undertaken by industry players and by government if driven primarily by one of the four overarching values shown in Table Sl. For example, in a situation driven mainly by economic values, restructuring plans would target the achievement of economic objectives such as increasing production efficiency and industrial competitiveness. However, in such a situation, it is also likely that many actions that 
Table S1. Guiding values and objectives for restructuring the u.s. electricity industry

\begin{tabular}{|c|c|c|c|}
\hline \multicolumn{4}{|c|}{ Values } \\
\hline Economic Progress & Social Equity & $\begin{array}{c}\text { Environmental } \\
\text { Stewardship }\end{array}$ & Social Sustainability \\
\hline \multicolumn{4}{|c|}{ Objectives } \\
\hline $\begin{array}{l}\text { * Economic Efficiency } \\
* \text { Industrial } \\
\text { Competitiveness } \\
\text { * Economic } \\
\text { Development } \\
\text { * Customer Choice }\end{array}$ & $\begin{array}{l}\text { * Equitable Sharing of } \\
\text { Costs and Benefits } \\
\text { * Public Participation } \\
\text { * Fair-trade Safeguards } \\
\text { * Protection of Human } \\
\text { Welfare }\end{array}$ & $\begin{array}{l}\text { * Clean Electricity } \\
\text { Generation and } \\
\text { Delivery } \\
\text { * Regional } \\
\text { Environmental } \\
\text { Quality }\end{array}$ & $\begin{array}{l}\text { * Proactive } \\
\text { Management of } \\
\text { Uncertainty } \\
\text { * Social Learning } \\
\text { * Community Stability }\end{array}$ \\
\hline
\end{tabular}

have been traditionally pursued by the electric industry would go undone. Such actions include much longterm public interest research (e.g., on human health and global climate change), much energy efficiency, much renewable energy, and low income programs. In a situation driven by social equity concerns, restructuring plans would most likely be quite different, with actions such as long-term portfolio and risk management and low income programs being emphasized at the expense of some other objectives. In a situation driven by environmental stewardship concerns, energy efficiency, renewable energy and pollution reduction programs would be emphasized with support for some social programs being traded-off. Lastly, in a situation driven by social sustainability concerns, long-term research and portfolio and risk management would be emphasized, possibly at the expense of some consumer-protection and low-income programs.

Explicitly describing such trade-offs is useful for several reasons. First, the exercise helps to clarify the values underlying restructuring debates. Second, it explains the enormous inertia to change in the electric industry. Third, it indicates that it will be virtually impossible to fully meet all key objectives without explicitly accepting and pursuing multiple values. And finally, it suggests that it will be difficult if not impossible to satisfy all four overarching values within a context that overlays retail competition upon an institutional structure best suited to regulate vertically-integrated electric utility monopolies. Larger institutional issues are largely being ignored, partly due to the emphasis of focus on market institutions, and partly because new ideas are needed.

Acting on this observation, a set of new ideas for institutions, programs, and financing mechanisms are introduced in the fourth section of this report. Five institutional innovations are proposed. The Regional Board of Directors (RBDs) is a multi-state institution that has the major responsibility for overseeing system service and transmission service organizations. Customer-owned franchises are awarded by state PUCs either along geographic or user-class criteria and have the responsibility for negotiating electricity service contracts (e.g., with power brokers) and implementing franchise-level government directives (such as 
portfolio standards). Electricity Facility Siting Marketplaces are designed to foster communication among communities to arrive at financially-attractive packages related to the location of new electric generation facilities, such as generation plants and transmission lines. Electric Industry Foresight Councils are charged with discussing the future of the industry, identifying risks and threats to the industry, and arriving at general, systemic responses to the threats. The Electric Industry Coordination Service has the responsibility for alternative dispute resolution and for proactively seeking to foster positive collaborations among industry players and the various governments. As a group, these institutions are logical outcomes of trends in society (e.g., toward regional institutions and electronic commerce) and represent attempts to complement economic goals (e.g., through foresight and coordination activities), rather than new methods to intervene in the marketplace.

It is recommended that government foster and have responsibility for several activities. The government should maintain a long-term, high-risk, high-payoff energy-sector research and development program. Built on this activity would be a more applied model systems program, which would feature the design, development and field demonstration of information-technology based systems that can provide a plethora of services. Tied to this program would be a program to integrate the provision of energy services, possibly with other closely tied social services such as housing. The potential for innovation in providing energy and social services is great. For example, ways to have service recipients collaborate with government in the provision of such services should be pursued. The government also needs to ensure that minimum service standards are set and met.

With respect to environmental and resource conservation issues, it is recommended that the government continue energy efficiency and emission cap/tax programs, institute portfolio standards at the franchise level, and work with the industry to adopt International Standards Organization (ISO) standards related to environmental and product quality. To assist in the design and implementation of all these programs, the government needs to conduct high quality, unbiased foresight and policy analyses.

With respect to financing, it is recommended that a national transmission (wires) charge, state-level universal distribution charge or all-fuels tax, and franchise-level sales tax be adopted. Low income subsidies and/or tiered electricity rates based on useage can be instituted to make this taxing regime more progressive.

In combination, these ideas work to balance as much as possible all four overarching values and associated objectives. With respect to economic progress, retail competition is preserved, the financial regime is based on electricity use, the environmental protection provisions are largely based on market principles, and many of the proposed government programs are intended to provide better services at lower cost. With respect to social equity, franchises provide a mechanism to foster faimess and participation, as does the Coordination Service and other government programs. Environmental stewardship is fostered by siting marketplaces, Foresight Councils and the mix of environmental protection mechanisms, from emission caps to portfolio and 
energy efficiency standards. Social sustainability is promoted through foresight activities, the social stability provided by franchises, the Coordination Service, and better provision of energy and social services. It needs to be noted that most of these ideas can be pursued separately, although valuable synergisms exist among the ideas.

Many issues require additional consideration. For example, what are the guidelines for creating and managing RBDs? Should franchises be customer-owned, government-owned, or incorporated as aggregators? Who should be allowed to make commitments in a siting marketplace and at what point are such commitments legally binding? Should industry players be required to participate in Foresight Councils? Exactly what energy service programs can be integrated? How should the national transmission charge, distribution charges, and franchise taxes be determined? There is no lack of important and challenging issues related to restructuring.

It is clear to us that it will be difficult if not virtually impossible to satisfy the overarching values of economic progress, social equity, environmental stewardship, and social sustainability by overlaying retail competition over an institutional framework developed to oversee and regulate the vertically-integrated monopoly-based utility-dominated electric power industry of the past. As shown in Section 3, profound trade-offs will need to be made which strike at the most dear values held by citizens and customers alike. On the other hand, as shown in Section 4, through institutional innovation and a great deal of hard work, approaches are possible that can indeed simultaneously satisfy all four overarching values.

As a final point, many of the ideas and problems presented herein can be expanded to encompass aspects of society and the economy that extend beyond the immediate concerns of the electric power industry. Each of the institutional recommendations can be expanded to include environmental concerns, for instance. Siting marketplaces can be used to discuss the siting of new prisons as well as new toxic waste incinerators and power generating facilities. Foresight councils can consider the profusion of global and national economic, political, social, technological, and environmental trends affecting society, many of which do indeed impact the electricity industry. New regional institutions may be necessary to deal with multi-jurisdictional environmental and infrastructure problems, in addition to electric industry problems. From an even broader perspective, the debates now taking place in the electric industry are a microcosim of fundamental debates that have engaged Americans since the founding of the nation. How to balance individualism and communitarianism, both of which have a place in American society, is extraordinarily complex. As this report shows, difficult tradeoffs await today's decision makers, as those in the past have faced. The report also communicates that there are always opportunities to pursue new ideas to better achieve balance in satisfying the multitude of important social values and objectives. 


\section{LIST OF ACRONYMS}

$\begin{array}{ll}\text { ADR } & \text { Alternative dispute resolution } \\ \text { DOE } & \text { Department of Energy } \\ \text { DSM } & \text { Demand-side management } \\ \text { FERC } & \text { Federal Energy Regulatory Commission } \\ \text { IRP } & \text { Integrated resource planning } \\ \text { ISO } & \text { International Organization for Standardization } \\ \text { NARUC } & \text { National Association of Regulatory Utility Commissioners } \\ \text { PUC } & \text { Public utility commission } \\ \text { R\&D } & \text { Research and development } \\ \text { SSO } & \text { System service organization } \\ \text { TSO } & \text { Transmission service organization }\end{array}$




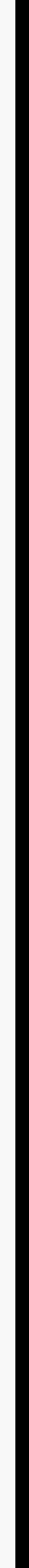




\section{TABLE OF CONTENTS}

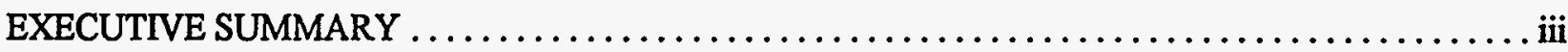

LIST OF ACRONYMS $\ldots \ldots \ldots \ldots \ldots \ldots \ldots \ldots \ldots \ldots \ldots \ldots \ldots \ldots \ldots \ldots \ldots \ldots \ldots \ldots \ldots \ldots \ldots \ldots$

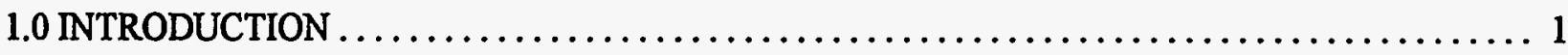

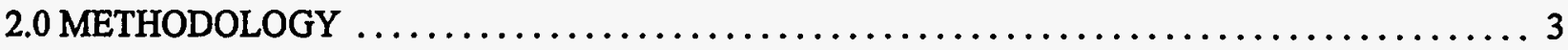

3.0 ALTERNATIVE SINGLE-VALUE REGULATORY RESPONSES $\ldots \ldots \ldots \ldots \ldots \ldots \ldots \ldots \ldots 7$

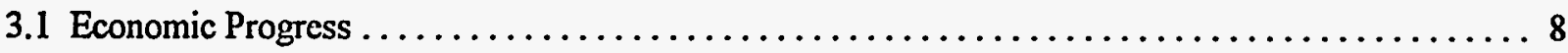

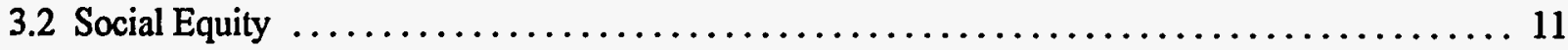

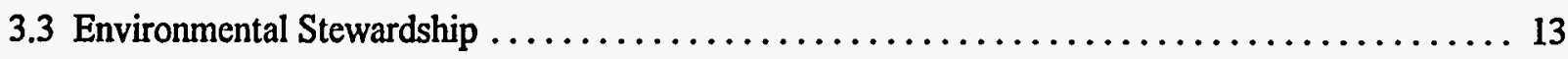

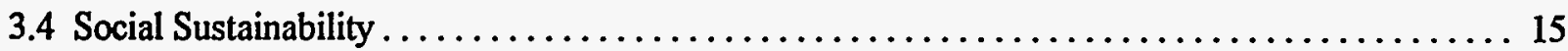

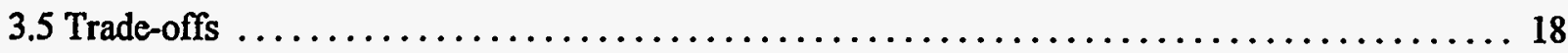

4.0 NEW IDEAS FOR SATISFYING PUBLIC POLICY RESPONSIBILITIES $\ldots \ldots \ldots \ldots \ldots \ldots$

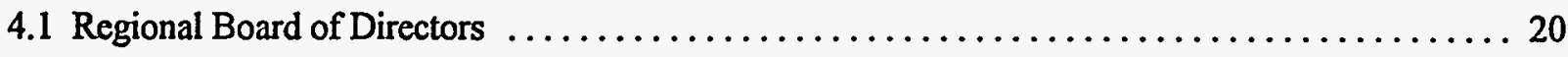

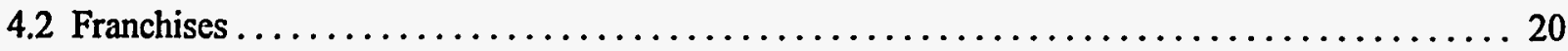

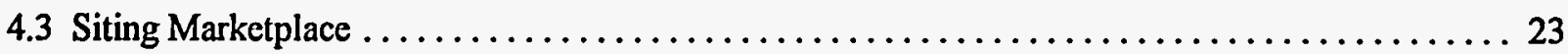

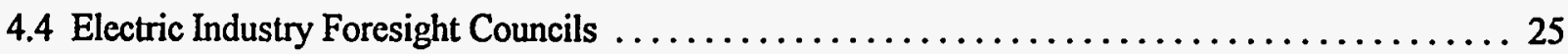

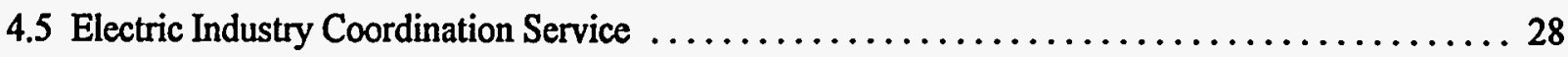

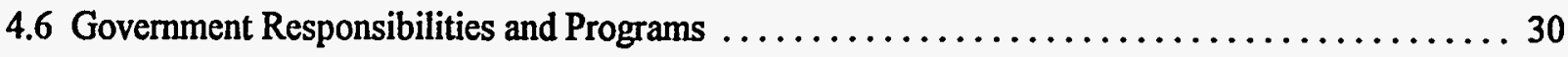

4.7 Revenue Sources for Meeting Public Policy Responsibilities .................. 35

4.8 Ownership, Reward Structures, and Other Considerations ................... 37

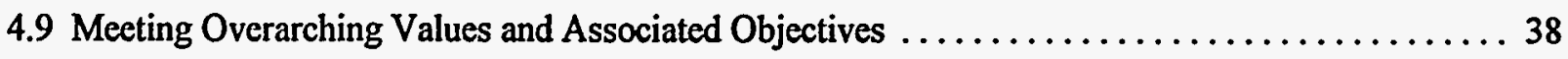

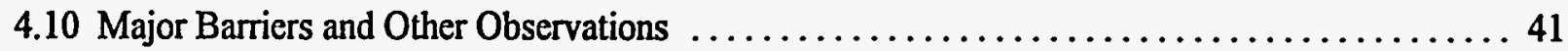

5.0 CONCLUDING REMARKS $\ldots \ldots \ldots \ldots \ldots \ldots \ldots \ldots \ldots \ldots \ldots \ldots \ldots \ldots \ldots \ldots \ldots \ldots \ldots$

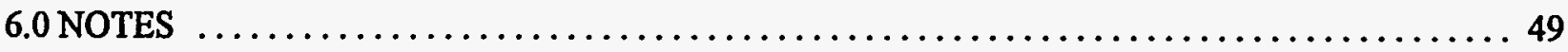

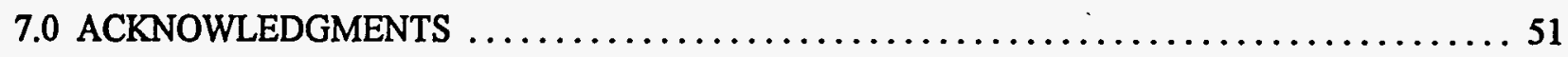

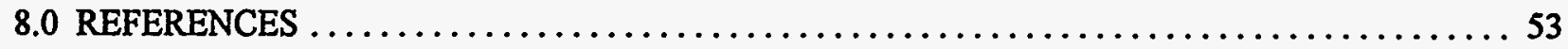




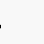




\section{LIST OF FIGURES}

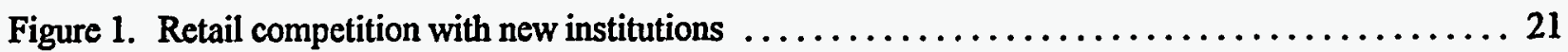

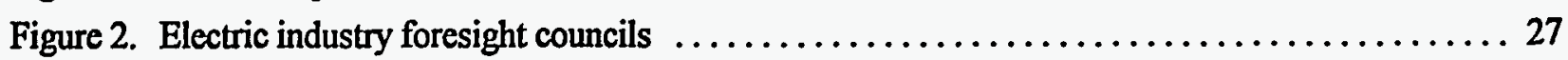

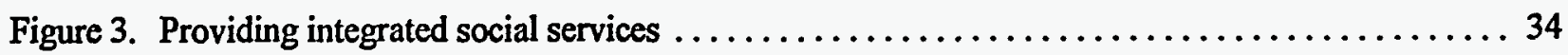

\section{LIST OF TABLES}

Table 1. Guiding values and objectives for restructuring the U.S. electricity industry $\ldots \ldots \ldots \ldots \ldots$

Table 2. Broad actions associated with the pursuit of public policy values and objectives $\ldots \ldots \ldots \ldots 5$

Table 3. Examples of government actions potentially useful for satisfying public policy responsibilities .. 5

Table 4. Actions likely to be taken when state regulators are primarily motivated by the value of economic

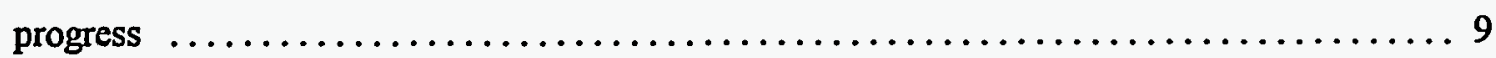

Table 5. Actions likely to be taken when state regulators are primarily motivated by the value of social

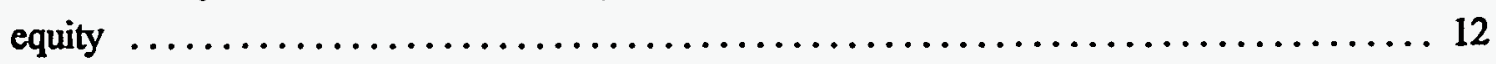

Table 6. Actions likely to be taken when state regulators are primarily motivated by the value of

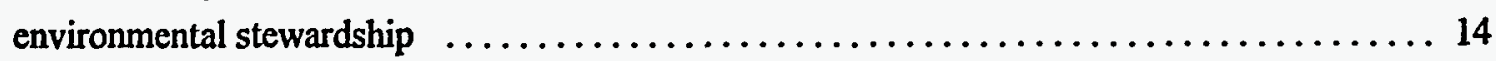

Table 7. Actions likely to be taken when state regulators are primarily motivated by the value of social

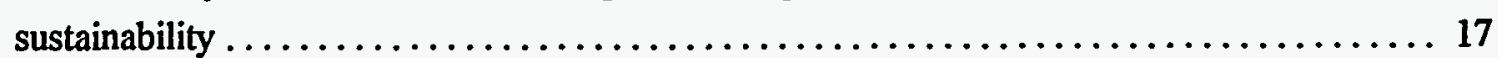

Table 8. Specific government programs and responsibilities ...................... 31

Table 9. Relationships between values/objectives of Section 2.0 and ideas presented in Section $4.0 \ldots 39$

Table 11. Key actions associated with different values $\ldots \ldots \ldots \ldots \ldots \ldots \ldots \ldots \ldots \ldots \ldots \ldots$

Table 12. Trade-offs associated with each single-value approach $\ldots \ldots \ldots \ldots \ldots \ldots \ldots \ldots \ldots \ldots$ 



\subsection{INTRODUCTION}

The United States electric power industry is in the initial phase of a sweeping restructuring, moving from a highly regulated, vertically integrated utility-based industry to a much less regulated, deintegrated, and highly competitive industry. Numerous issues are receiving vigorous debate, including how to deal with stranded investments and how to ensure fair access to transmission services. The topic of interest here is how to satisfy public policy responsibilities in a restructured industry.

Historically, electric utilities, typically at the behest of their public utility commissions (PUCs), provided a range of public interest programs, including demand-side management (DSM), integrated resource planning (IRP), low income weatherization, and the use of renewables. How, and even if, the objectives represented by such programs will be satisfied in the future is a major question facing policy makers. This is because there is a fundamental conflict between the free market and such public policy benefits.

There is no lack of statements of principle concerning what programs and objectives ought to be maintained into the future. For example, see Tierney (1994), the California Public Utilities Commission (1994), the New York Public Service Commission (1994), Cullen et al. (1994), Hamrin et al. (1994), and the Electricity Consumers Resource Council (1994). A recent proclamation of principles emanating from the Massachusetts Electric Industry Roundtable (1995) includes the following programs and objectives: reliability; fairness and consistency; benefits to all customer classes; recovery of stranded costs; choice at the retail level; environmental improvement; cost effective DSM; and universal service.

Tonn, Hirst, and Bauer (1995) summarize many lists of statements of principles and present a framework to assist the development of alternative strategies and approaches for satisfying the principles. The framework includes: four overarching public policy values \{economic progress, social equity, environmental stewardship, and social sustainability\}; more specific public policy objectives; implementable public policy actions and mechanisms; and considerations of what markets and government can do well and not so well. The purpose of this project is to extend this research by: exploring the necessary trade-offs of pursuing each overarching public policy value over the others; and constructing a multi-faceted approach for addressing all four overarching values simultaneously in future. This project will be successful if the analyses and ideas presented herein further discussions about and lead to innovative approaches for meeting public policy responsibilities in a restructured electric industry.

Section 2.0 summarizes the framework presented by Tonn, Hirst and Bauer (1995) and presents the methodology for this project. Using the framework, five different approaches to meeting public policy responsibilities are explored. The first four approaches, discussed in Section 3.0, take as given an industry that is highly competitive but still characterized by regulators who have influence over 'utilities;' we suggest 
those actions that are likely to be taken, and not taken, in the near-term in the event that each of the four key values, in turn, is emphasized by state regulators over all the others. The fifth approach, discussed in Section 4.0 , takes as given a completely deintegrated electric industry characterized by retail competition and posits a longer-term, more fully-developed portfolio of institutions and actions for addressing all four overarching values in a manner designed to spawn new and innovative ideas. 


\subsection{METHODOLOGY}

The goal of this research is to explore the possible effects of different values emphases and to suggest a possible approach for satisfying all key public policy responsibilities in a restructured electric power industry. Table 1 contains the values used in this study. Each of the four overarching public policy values can be satisfied by achieving more specific objectives. The values of economic progress, social equity, and environmental stewardship and their associated objectives were distilled from numerous lists of stated principles and from discussions at the April 1995 workshop on Public-Policy Responsibilities and Electric Industry Restructuring. Definitions of these values and objectives are in Tonn, Hirst and Bauer (1995), Appendix B. The value of social sustainability and its associated objectives are taken from Tonn and White (1995), who attempt to characterize societies that have the ability to survive over extended time periods to be able to carry out long-term plans associated with sustainable development and global environmental protection. Because electric power is a major component in any envisionable future society and because the generation of electricity has major effects upon the global environment, we believe that this value and the associated objectives should be included in this study. In many ways, social sustainability can be thought of as arising from the combination and successful balancing of the other three values.

We do not argue that our list of values and objectives is definitive; reasonable people most assuredly could differ on this point. However, we do argue that the list is sufficiently comprehensive and informed to provide a foundation for this research.

Central to the debate about electric industry restructuring are the relative roles of markets versus government regulated industries and programs in providing electricity services to meet values and objectives, such as those set out in Table 1. At the extremes, objectives that can be met well by markets ought not to be undertaken by government and objectives that are deemed important and are likely not to be met at all by markets ought to be the responsibility of government. Where specific objectives and actions fall within the continuum bounded by these extremes can be hotly disputed. To help us understand the various arguments and to assist us in designing better alternatives, we set out lists of strengths and weaknesses of both markets and government programs. Again for a fuller but by no means complete discussion, see Tonn, Hirst, and Bauer (1995).

Markets have many strengths. Buyers and sellers are free to negotiate prices and the sales of goods and services, which maximizes economic efficiency and consumer surplus. Through price signals, markets can quickly adjust to changes in preferences and the costs of production inputs, and to challenges of national and global competition. However, markets fail to perform in these manners: in the presence of unregulated monopolies and other factors which unfairly favor buyers or sellers; when externalities are not priced or are mispriced; and when public goods are involved. In addition, markets may not achieve certain hoped for goals 
Table 1. Guiding values and objectives for restructuring the U.S. electricity industry

\begin{tabular}{|c|c|c|c|}
\hline \multicolumn{4}{|c|}{ Values } \\
\hline Economic Progress & Social Equity & $\begin{array}{l}\text { Environmental } \\
\text { Stewardship }\end{array}$ & Social Sustainability \\
\hline \multicolumn{4}{|c|}{ Objectives } \\
\hline $\begin{array}{l}\text { * Economic Efficiency } \\
\text { * Industrial } \\
\text { Competitiveness } \\
\text { * Economic } \\
\text { Development } \\
\text { * Customer Choice }\end{array}$ & $\begin{array}{l}\text { * Equitable Sharing of } \\
\text { Costs and Benefits } \\
\text { * Public Participation } \\
\text { * Fair-trade Safeguards } \\
\text { * Protection of Human } \\
\text { Welfare }\end{array}$ & $\begin{array}{l}\text { * Clean Electricity } \\
\text { Generation and } \\
\text { Delivery } \\
\text { * Regional } \\
\text { Environmental } \\
\text { Quality }\end{array}$ & $\begin{array}{l}\text { * Proactive } \\
\text { Management of } \\
\text { Uncertainty } \\
\text { * Social Learning } \\
\text { * } \text { Community Stability }\end{array}$ \\
\hline
\end{tabular}

when: they may not materialize due to lack of demand or too high production costs; intellectual property cannot be protected; financial and/or human capital is not available; and products cannot be produced which can directly achieve the goals.

For government policies and programs to succeed, the following four criteria must be met: (1) the specific action or service to be undertaken must be clearly describable; (2) the public must support the values and objectives to be satisfied by the action; (3) there must be a cultural association of the action with government; and (4) the specific action must be reasonably implementable from an operational standpoint. Governments have shown that they are good at some activities; such as collecting revenues, setting standards, and providing some standard services. In the US, many but not all state and local governments have great difficulty in planning, taken in its broadest context, and in cooperating across jurisdictional boundaries. As a final point, while we believe that government can be made more efficient, success of government ought not to be based on the same criteria as used to measure success for markets because government programs must satisfy broader criteria and often undertake projects that are too difficult, too controversial, or just plain inappropriate for the private sector.

To satisfy values and objectives within the performance constraints of markets and government, one can piece together a set of policies and actions into coherent programmatic approaches. The approaches will necessarily have laissez-faire aspects as well as specific tasks for government. Different approaches will present different combinations of these factors. Table 2 lists broad actions which have been pursued by electric utilities and government programs within the context of a vertically integrated industry. Table 3 contains additional examples of government actions that could possibly be included in any design of a comprehensive program to satisfy public policy responsibilities in a restructured electric industry. Tonn, Hirst and Bauer (1995) contains descriptions of these actions. 
Table 2. Broad actions associated with the pursuit of public policy values and objectives

- Research and development

- System reliability

- Portfolio/risk management

- Demand-Side Management

- Non-discriminatory transmission access

- Low-income programs

- Minimum service standards

- Consumer protection

- Fair treatment of stranded commitments

- Renewable energy

- Pollution reduction

Table 3. Examples of government actions potentially useful for satisfying public policy responsibilities

\begin{tabular}{|l|l|l|}
\hline \multicolumn{1}{|c|}{ Taxes and Tax Incentives } & \multicolumn{1}{|c|}{ Regulatory Levers } & \multicolumn{1}{c|}{ Programmatic Activities } \\
\hline * Distribution Charge & $*$ Portfolio Standards & * Long-Term R\&D \\
* Uplift Charge & $*$ Government Created Markets & * National Nonprofit R\&D \\
* National Wires Charge & * Emission Caps & Center \\
* Energy Charge & * Retail Licenses & * Low Income Programs \\
* Emissions Fees & $*$ Green Electron Wheeling & * Non-profit organizations \\
* General Taxes & * Biddable Franchises & * State Integrated Resource \\
* Tax Credits & * Performance-Based & Plans \\
* Trust Funds & Regulation & Regional Transmission \\
& * Federal Transmission Access & Groups \\
& Regulations & * Interstate Compacts \\
& * Environmental Regulations & * Joint State Boards \\
& * Power Plant Siting and & * Advocates \\
& Certification & * Information Programs \\
& $*$ Energy-Efficiency Standards & * Energy-Efficiency Mortgages \\
\hline
\end{tabular}

Five different approaches to meeting key values and objectives are presented in the balance of this report. The first four, discussed in Section 3.0, are designed to stress one of the four overarching values above the others. Thus, for example, the alternative outlined in Sect. 3.1 stresses economic progress and the alternative 
in Sect. 3.2 stresses social equity. The assumption underlying this approach is that in the short-term, different states are likely to emphasize one or the other values in the restructuring process. This does not mean that other values and objectives would be neglected completely. It just means that it is convenient to anchor discussions about a very complex topic that involves numerous stakeholders on fewer rather than more key considerations. Thus, these four single-value regulatory responses are designed to provide policy makers with insights into the possible results of the pursuit of each of the values and the associated objectives.

The fifth approach, presented in Section 4.0, suggests an innovative programmatic scheme for addressing all four overarching values and associated objectives. We have no illusions that all the ideas will be adopted by any state or group of states in the near-term or that every new idea is sufficiently thought out to guarantee its successful implementation. Nevertheless, we believe that the industry must continually consider new ideas, especially at a time of change when new ideas may be more valuable and easily adopted. With respect to current debates on restructuring, we believe that new potential institutional relationships are largely being ignored, partly because of the dominance of market values in the current debate and partly because few new ideas have been proposed, possibly because it is believed that new institutional relationships are unneeded and that new institutional relationships are seen as synonymous with 'big government'. We find that there are opportunities for new institutional forms, some designed explicitly upon advanced information technologies, that may well satisfy all four overarching values, without overly constraining the private sector or resulting in overly bureaucratic organizations. It is within this context that the fifth approach has been conceived. 


\subsection{ALTERNATIVE SINGLE-VALUE REGULATORY RESPONSES}

In the near-term future, in a more competitive and less regulated electric industry but one still characterized by utilities and their regulators, it is likely that public policy responsibilities will tend to be met in the following general manner: utilities will take those actions they define as being in their best interests; state and federal lawmakers and executive agencies will require utilities to take additional actions, to the extent that such requirements are ideologically acceptable to government officials and politically acceptable to their constituents; state government agencies will directly take those politically and economically feasible actions that utilities have not taken; and some possible actions for achieving public policy values and objectives will not be taken at all.

Federal actions are likely to focus on non-discriminatory transmission access (already addressed on the wholesale level by FERC), fair treatment of stranded commitments (addressed by FERC in cases of municipalization and currently under consideration by many state PUCs), and pollution reduction technologies. In addition, federal funds will probably continue to be used for low-income weatherization. In the current political climate, federal actions in the area of renewable energy research and development are likely to be reduced.

Specific actions that are taken by the other key parties will vary from state to state and from utility to utility. The states will vary in their actions based on existing political, ideological, and economic differences. Some states may choose to require or perform relatively few actions, while others are likely to play a much larger role in discharging public policy responsibilities. And some utilities will find it in their best interests to take more (or fewer) actions than their cohorts will and this is likely to be influenced by the attitudes of state regulators, public opinion, and tradition.

This Section explores which of the broad actions shown in Table 2 are likely to be taken over the next one to three years by the key parties under four prototypical situations: (1) state regulators are primarily motivated by the value of economic progress; (2) state regulators are primarily motivated by the value of social equity; (3) state regulators are primarily motivated by the value of environmental stewardship; and (4) state regulators are primarily motivated by the value of social sustainability. We acknowledge that, in reality, state regulators often hold multiple values and attach considerable importance to a number of different and potentially competing objectives. Accordingly, real-life situations are rarely as simple and clear-cut as they are in the four cases discussed below. Nonetheless, we believe that the exploration of the effects associated with these single-value regulatory responses can be instructive by focusing on the consequences of pursuing each value separately. 
All four single-value approaches presented in this report assume that current trends toward competition in the utility industry will continue. We also assume that conditions will differ, often markedly, among the states and that state regulators will continue-at least for the next few years-to exercise considerable control over the electric industry, although we expect competition and customer choice to increase. The advent of retail access on a broad scale is not part of the near-term future explored here. As illustrated in the four singlevalue approaches discussed below, we believe that the values held by state regulators-PUCs as well as environmental agencies-will strongly influence actions taken voluntarily by utilities and also will be reflected in actions mandated or taken directly by the regulators. As state regulators change, or as their values do, significant changes in regulatory decisions and private sector actions can be anticipated. It is likely that-in general-the influence of regulators will decline substantially as the electric industry moves closer to retail access but, in the near-term future described in this Section, the influence exerted by regulators is assumed to still be considerable.

\subsection{Economic Progress}

The value of economic progress is associated with the following four broad objectives: economic efficiency; industrial competitiveness; economic development; and customer choice. It is important to note that "economic efficiency," as used in this report, refers primarily to production efficiencies and does not include the efficiency with which products are used by consumers. In line with the four objectives, six broad actions are likely to be emphasized most strongly when the primary value of regulators is economic progress. These actions are: (1) the development component of research and development, aimed at giving private sector actors a competitive edge; (2) system reliability, as a way of getting and keeping customers; (3) the load management and load building parts of DSM, plus some industrial energy efficiency efforts; (4) nondiscriminatory transmission access, with an emphasis on allowing suppliers to compete with each other and allowing large customers to receive attractive rates; (5) minimum service standards dealing with technical specifications for power quality and customer service; and (6) treatment of stranded commitments, to balance the interests of electric utilities and prospective large retail customers as states prepare for retail access. In general, these actions are likely to reinforce, rather than moderate, the competitive forces currently at work in the electric industry. Table 4 shows the specific actions likely to be taken by various actors-and those that are likely to go undone-in states where the regulators are primarily motivated by the value of economic progress.

In the area of research and development, the private sector is expected to voluntarily pursue the development of programs aimed at giving them an advantage over their competitors, while putting little emphasis on longterm research serving broader public interests. Private sector actors also are likely to continue following established procedures to ensure system reliability. Electricity providers would probably engage in some resource portfolio/risk management in the form of the development of strategies to prepare for a variety of 
Table 4. Actions likely to be taken when state regulators are primarily motivated by the value of economic progress

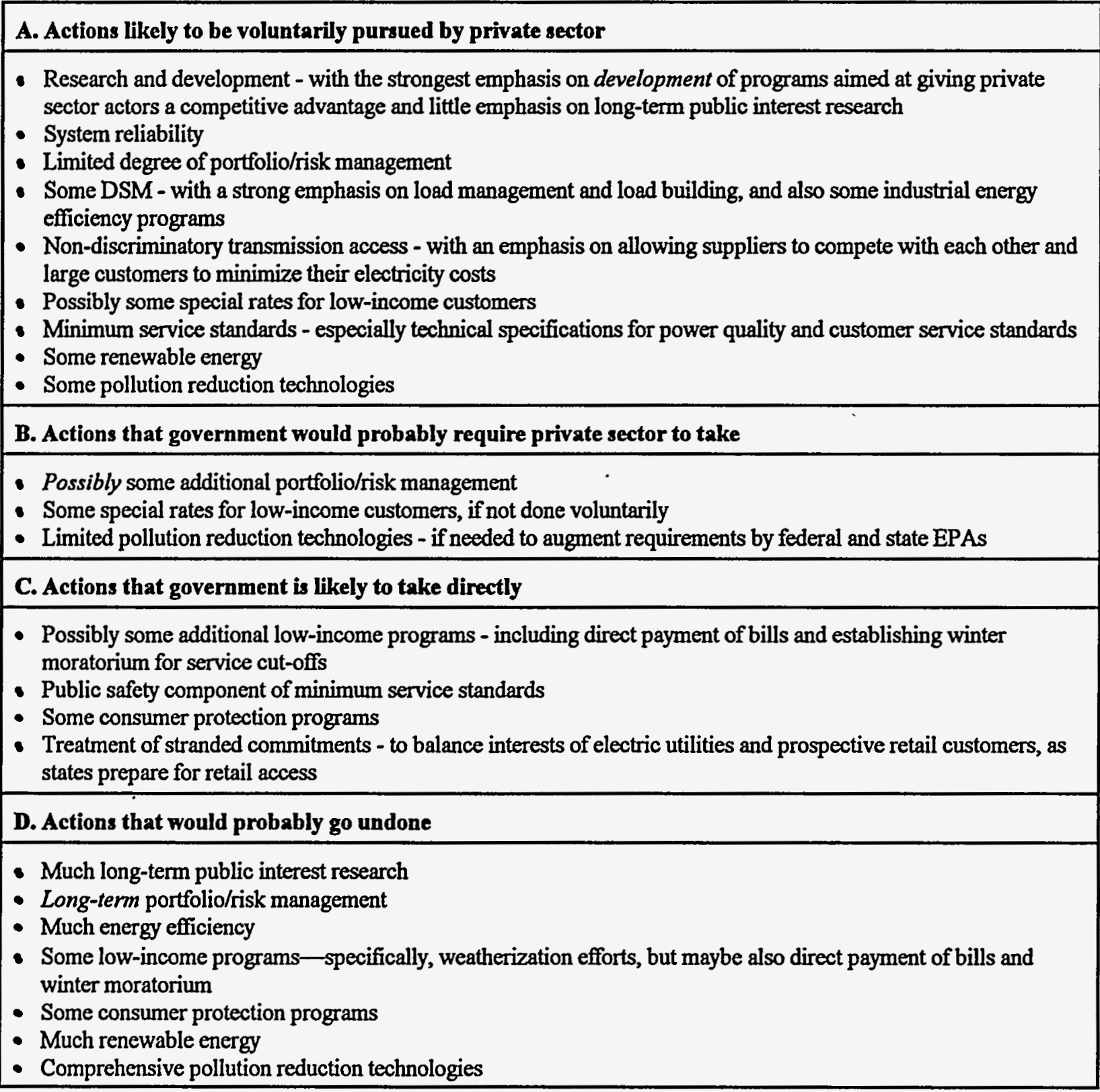

future occurrences, but these would primarily address the near-term future. It is also likely that electricity suppliers would provide some DSM and renewable energy resources, but only to the extent that these are cost-effective and/or aid in customer retention. Accordingly, the strongest DSM emphasis would probably be on load management and load building programs, but it is possible that electricity providers would also find it worthwhile to help large industrial customers with their energy efficiency efforts as a customer-retention tool. In addition, energy service companies might find it profitable to provide additional energy efficiency services 
in a more competitive electric industry. Some pollution reduction technologies are likely to be pursued by electricity generators, to the extent that they are cost-effective and have public relations value for the company providing them. And some private sector actors might take steps to actively support-and even expand - existing FERC initiatives aimed at assuring non-discriminatory transmission access, for the purpose of allowing suppliers to compete with each other and in recognition of regulators' interest in allowing large customers to minimize their electricity costs. There is likely to be a strong interest in technical specifications for power quality and customer service standards, because both of these would be helpful in getting and keeping customers. The private sector also might voluntarily provide some special rates for low-income customers, provided that state regulators allow cost recovery.

In addition to those actions that the private sector would pursue on its own, there are others that the government would probably require the electricity industry to take. Even with economic progress being the primary value motivating regulators, the states are still likely to be concerned with providing a minimum safety net of electricity services for the poor. Therefore, some state governments are likely to require the establishment of special rates to protect low-income customers if such rates are not provided voluntarily by electricity suppliers. Similarly, some use of pollution reduction technologies would probably be required to provide the minimum level of environmental protection demanded by society. In addition, it is possible that the state would require the private sector to engage in some additional portfolio/risk management (beyond the level that would be done voluntarily) in order to ensure the continued availability of electricity over a longer time frame and in the face of more widely varying conditions than might have been addressed without this regulatory push.

With economic progress being the regulators' primary value, government would probably take steps to address the issue of stranded commitments. In the spirit of competition and economic progress, it is likely that utilities would be expected to assume a fair amount of the burden of stranded costs, allowing customers that leave the existing system to realize substantial cost savings. However, existing utilities would probably be offered some protection-in the form of policies and regulations governing the recovery of stranded costs-in order to balance the interests of electric utilities and prospective retail customers as states prepare for retail access. In addition, it is likely that the states would provide some consumer protection programs and would mandate minimum service standards addressing public safety. It also is possible that state governments would require additional low-income programs, such as direct payment of bills for needy customers and the establishment of a winter moratorium on the cut-off of electric services.

Finally, there are a substantial number of possible actions that are likely to go undone or to be performed only partially. Long-term public interest research would probably not be performed to any large extent, nor would the full range of available pollution reduction technologies be utilized. Many energy efficiency options would probably not be used because-in the absence of regulatory incentives-they would not be economically attractive, particularly in the near-term; however, the future level of activity of energy service companies is 
still very uncertain. Many renewable energy resources would probably not be used and some consumer protection programs are likely to go undone. Some low-income programs likewise would probably not be provided because of the requisite costs; this most likely would mean an absence of low-income weatherization efforts but it could also extend to the direct payment of bills and winter moratorium programs. And long-term portfolio/risk management would probably not be done because of the more immediate concern with shortterm competitiveness. What this means is that the objectives associated with environmental stewardship would be met minimally, if at all. And a majority of the actions associated with social sustainability would probably not be taken under this approach. Likewise, most of the actions associated with key social equity objectives would not be met, with protection of human welfare and public participation being especially hard hit.

\subsection{Social Equity}

Four broad objectives are associated with the value of social equity: equitable sharing of costs and benefits; public participation; fair-trade safeguards; and protection of human welfare. Accordingly, the following actions are likely to be emphasized most strongly when regulators' primary value is social equity: (1)longterm portfolio and risk management for the purpose of ensuring adequate and affordable power for all customers in the future; (2) non-discriminatory transmission access, with the emphasis on assuring equal access for all customer classes; (3) low-income programs-especially special rates, direct bill payments, and a winter moratorium on service cut-offs; (4) the safety and consumer-protection parts of minimum service standards; (5) consumer protection programs; and (6) stranded commitments, with an emphasis on balancing the interests of shareholders and ratepayers. Table 5 details those actions likely to be taken-and not taken-in states where the regulators' primary value is social equity.

Where there is a strong regulatory interest in social equity, the private sector is likely to respond to this through a number of "voluntary" actions. For instance, the private sector is expected to emphasize long-term public interest research aimed at safeguarding and/or improving conditions for a broad range of societal groups in order to assure good relations with state regulators. At the same time, electricity providers are likely to undertake some short-term program development efforts as well. Actions to ensure system reliability will be undertaken, and it is likely that some minimum service standards, especially in the areas of public safety and consumer protection, will be voluntarily created in order to protect the public interest. In line with regulators' priorities, electricity providers are likely to engage in long-term portfolio and risk management in an effort to provide adequate and affordable power for all customers in the future. In addition, the private sector is likely to support non-discriminatory transmission access for the purpose of encouraging lower rates for consumers and assuring equal access for all customer classes. The private sector is unlikely to be strongly encouraged by state regulators to provide DSM programs. As a result, the primary emphasis in the DSM arena is expected to be on load management, which electricity providers are more likely to find cost-effective 
Table 5. Actions likely to be taken when state regulators are primarily motivated by the value of social equity

\begin{tabular}{|l|}
\hline A. Actions likely to be voluntarily pursued by private sector \\
\hline - Research and Development - emphasis on long-term public interest research, but also some short-term program \\
development \\
- System reliability \\
- Long-term portfolio and risk management - for the purpose of ensuring adequate and affordable power for all \\
- Some DSM - primarily load management \\
- Nondiscriminatory transmission access - for purpose of encouraging lower rates for consumers and assuring equal \\
- Sccess for all customer classes \\
- Minimum service standards - especially public safety and consumer protection \\
- Possibly some consumer protection programs \\
- Some renewable energy \\
- Some pollution reduction technologies \\
B. Actions that government would probably require private sector to take \\
\hline - Long-term portfolio/risk management \\
- Additional actions to assure equal transmission access and fair rates for all customer classes \\
- Limited pollution reduction technologies - if needed in addition to federal and state EPA requirements \\
C. Actions that government is likely to take directly \\
\hline - Additional low-income programs - particularly direct bill payments and winter moratorium, and possibly \\
weatherization efforts \\
- Minimum service standards - especially customer service \\
- Consumer protection programs \\
- Treatment of stranded commitments - with an emphasis on balancing the interests of shareholders and ratepayers \\
\hline D. Actions that would probably go undone \\
\hline - Much DSM - particularly energy efficiency, since load management and load building will continue to be in \\
utilities' interest in a competitive environment \\
- Comprehensive pollution reduction technologies \\
\hline
\end{tabular}

than energy efficiency. Special rates for low-income customers would probably be provided by some electricity suppliers in the interest of pleasing state regulators. It also is possible that the private sector would provide some consumer protection programs, although this is likely to continue to be the domain of government. Finally, some renewable energy resources and pollution reduction technologies are likely to be voluntarily utilized by the private sector.

Where the primary value of state regulators is social equity, we expect that long-term portfolio/risk management would be required, so that constant and dependable electricity is assured for all classes of society. In addition, the private sector would probably be required to take additional actions to assure equal 
transmission access and fair rates for all customer classes. And limited pollution reduction technologies are likely to be mandated, if needed to augment existing federal and state Environmental Protection Agency requirements.

When the interest in social equity is paramount, it is likely that government would directly provide some lowincome programs to augment those provided by the private sector; these would probably include direct bill payments and a winter moratorium on service cut-offs and possibly low-income weatherization programs as well. Government's strong interest in the fair treatment of all segments of society also would probably lead to the establishment of minimum service standards-especially in the area of customer service-and consumer protection programs. And it is likely that government would address the treatment of stranded commitments, with an emphasis on balancing the interests of shareholders and ratepayers by requiring each to shoulder that share of the burden that is consistent with regulators' social equity concerns.

Many fewer possible actions would probably go undone in this case than where regulators' primary value is economic progress. Still, numerous energy efficiency and renewable energy opportunities are likely to go untapped because their full use is not in the economic interest of the private sector nor central to the value of social equity, which is driving this approach. Similarly, a comprehensive range of pollution reduction technologies is not expected to be developed in this case. Not surprisingly, all of the major objectives associated with the value of social equity are expected to be thoroughly satisfied. In addition, all of the economic progress objectives would be met and all objectives attached to the value of social sustainability would be satisfied, although the proactive management of uncertainty and community stability would both be weakened slightly by the failure to utilize the full range of available DSM, renewable energy, and pollution reduction options. However, the lack of a full range of options in these areas has its most serious effect on the value of environmental stewardship, where the ability to meet the objectives of regional environmental quality and clean electricity generation/delivery is seriously diminished.

\subsection{Environmental Stewardship}

In this case, environmental stewardship is the primary value held by state regulators. This value is associated with two objectives: clean electricity generation and delivery; and regional environmental quality. When regulators' primary value is environmental stewardship, the greatest emphasis is likely to be put on the following actions: (1) research on environmentally benign technologies; (2) long-term portfolio and risk management, for the purpose of ensuring an environmentally benign mix of resources; (3) energy efficiency programs, for the purpose of minimizing emissions; (4) renewable energy technologies; and (5) pollution reduction efforts. The specific actions likely to be taken - and left undone-by the key parties are shown in Table 6. 
Table 6. Actions likely to be taken when state regulators are primarily motivated by the value of environmental stewardship

\begin{tabular}{|l|}
\hline A. Actions likely to be voluntarily pursued by private sector \\
\hline - Research and Development - stressing research on environmentally benign technologies \\
- System reliability \\
- Some long-term portfolio and risk management - for purpose of ensuring environmentally benign mix of resources \\
- Non-discriminatory transmission access \\
- Possibly some special rates for low-income customers \\
- Some minimum service standards - especially public safety \\
- Some renewable energy \\
- Maybe some consumer protection programs for the purpose of assuring customers that they are really getting \\
"environmentally clean" power \\
\hline B. Actions that government would probably require private sector to take \\
\hline - Additional long-term portfolio/risk management \\
- Additional DSM - especially energy efficiency \\
- Additional renewable energy \\
\hline C. Actions that government is likely to take directly \\
\hline - Additional Research and Development \\
- Possibly some additional DSM - especially energy efficiency \\
- Additional low-income programs - emphasizing weatherization and maybe direct payment of bills and winter \\
- Soratorium \\
- Treatment of stranded commitments - to protect any rate-based utility investments in DSM and renewables \\
- Possibly some additional renewable energy \\
- Possibly some additional pollution reduction technologies \\
D. Actions that would probably go undone \\
\hline - Sossibly some low-income programs - specifically direct payment of bills and winter moratorium \\
\hline
\end{tabular}

We expect to see the private sector voluntarily engage in Research and Development activities, with an emphasis on research focused on environmentally-benign technologies as a way of maintaining and improving relations with state regulators. System reliability also will be pursued, as in the previous cases. In addition, electricity providers would probably engage in some long-term portfolio and risk management for the purpose of ensuring an environmentally sensitive mix of resources. In response to their perceptions of regulatory preferences, private sector actors are likely to voluntarily pursue the use of some energy efficiency programs that serve to reduce harmful emissions, and load management programs also will be provided. The electric industry also is expected to utilize a broader range of renewable energy resources and pollution reduction technologies than would be dictated by cost-effectiveness alone, in order to achieve and/or maintain 
good relations with state regulators. Non-discriminatory transmission access will probably be sought by the private sector, and it also is likely that minimum service standards dealing with public safety will be voluntarily created. In addition, it is possible that special rates for low-income customers would be voluntarily provided by some electricity suppliers, and that some consumer protection programs would be created for the purpose of assuring concerned customers that they are really getting "environmentally clean" power.

Government is expected to require the electric industry to perform additional portfolio/risk management, with an emphasis on ensuring an environmentally benign resource portfolio for both the short- and long-term futures. Toward the same end, electricity providers are likely to be required to use even more energy efficiency, renewable energy, and pollution reduction technologies than they would voluntarily do in response to regulators' preferences.

Because of their overriding interest in environmental stewardship in this case, we expect to see government agencies directly take a number of actions in addition to those performed by the private sector. Additional Research and Development is likely to be performed, for the purpose of generating new options for providing electricity in the most environmentally benign manner possible. Governments also might provide some additional energy efficiency programs, renewable energy resources, and pollution reduction technologies directly, and they could enact nonbypassable service/wires charges to pay for these expenditures. Such a mechanism also could be used to fund government-mandated programs provided by the private sector. Additional low-income programs are likely to be provided; these will include weatherization efforts and maybe also the direct payment of bills and the establishment of a winter moratorium on service cut-offs. Likewise, some consumer protection programs will probably be established by state government. And we expect to see the enactment of regulations on stranded commitments that help protect any rate-based investments that utilities have made in DSM and renewable energy resources by allowing the recovery of these costs from departing customers.

Under this approach, the only actions that are likely to go undone are the provision of some consumer protection programs, some minimum service standards, and possibly some low-income programs - because they are not central to the value of environmental stewardship. The lack of these actions reduces somewhat the extent to which social equity objectives are met, with the greatest adverse affect on the objective of protecting human welfare. Social sustainability also is slightly compromised, with the greatest hit taken by the objective of social learning.

\subsection{Social Sustainability}

The final single-value approach presented in this report highlights social sustainability, which refers to the ability of a society to collectively craft and implement long-term plans that will improve its members' quality of life and the quality of the global environment, on a continuing basis. The value of social sustainability is 
associated with the following three broad objectives: proactive management of uncertainty; social learning; and community stability. Proactive management of uncertainty refers to society's ability to identify sources of uncertainty, to creatively construct potential decision alternatives, and to work together to determine the best course of action. Social learning is the acquisition and use of human knowledge for the common good, and includes the evaluation of a society's own strengths and weaknesses and the development of ways to solve identified problems. Community stability can be described as the ability to endure and resist deterioration, and is often marked by a set of shared interesst, affinities, cultural practices, and social values. In line with these objectives, the following actions are likely to be emphasized most strongly when the primary value of state regulators is social sustainability: (1) long-term research on new and diverse technologies, especially those that are environmentally benign; (2) long-term portfolio and risk management, to ensure a stable future electricity supply; (3) energy efficiency programs, to prepare for possible shortages of conventional fuels; (4) many kinds of minimum service standards, specifically public safety, technical specifications for power quality, consumer protection, and customer service; (5) fair treatment of stranded commitments to ensure long-term viability of the electric industry; (6) renewable energy, to prepare for possible future fuel shortages; and (7) pollution reduction to keep the environment clean and safe for future generations. Table 7 shows the specific actions that are likely to be taken —and by whom —in states where regulators are primarily motivated by the value of social sustainability.

Research and Development would probably be voluntarily performed by the private sector, with an emphasis on finding and developing new and diverse technologies, especially those that are environmentally benign. And as with all the cases discussed previously, system reliability is expected to be addressed by the private sector. Long-term portfolio/risk management is likely to be performed in order to ensure an environmentally sensitive mix of resources and a secure, long-term supply of electricity. The private sector is expected to voluntarily utilize some energy efficiency and load management options as well as some renewable energy resources and pollution reduction technologies, all in the interest of limiting air emissions and protecting the environment. Non-discriminatory transmission access will be sought, and some special rates for low-income customers are likely to be provided. Minimum service standards addressing public safety and consumer protection also would probably be voluntarily created by the private sector in line with perceived regulatory priorities.

Regulators are likely to require additional long-term portfolio/risk management for the same reasons given above. Government will probably also mandate the use of more energy efficiency and renewable energy resources, to prepare for possible future shortages of conventional fuels. In addition, the utilization of more pollution reduction technologies is likely to be required, for the purpose of protecting environmental quality for future generations. 
Table 7. Actions likely to be taken when state regulators are primarily motivated by the value of social sustainability

\section{A. Actions likely to be voluntarily pursued by private sector}

- Research and Development - with emphasis on new and diverse technologies, especially those that are environmentally benign

- System reliability

- Long-term portfolio/risk management - to ensure environmentally benign mix of resources and long-term electricity supply

- Some DSM - load management and energy efficiency

- Non-discriminatory transmission access

- Some special rates for low-income customers

- Some minimum service standards - particularly public safety and consumer protection

- Some renewable energy

- Some pollution reduction technologies

B. Actions that government would probably require private sector to take

- Still more portfolio/risk management

- More DSM - especially energy efficiency, to prepare for possible shortages of conventional fuels

- More renewable energy - to prepare for possible shortages of conventional fuels

- More pollution reduction technologies - to keep environment clean for future generations

C. Actions that government is likely to take directly

- Possibly some additional DSM - emphasizing energy efficiency

- Some minimum service standards - particularly technical specifications for power quality and customer service standards

- Additional low-income programs - weatherization efforts, winter moratorium, and possibly direct payment of bills

- Some consumer protection programs

- Treatment of stranded commitments - to ensure long-term viability of utility industry

- Possibly some additional renewable energy

- Possibly some additional pollution reduction technologies

D. Actions that would probably go undone

- Possibly some low-income programs - specifically direct payment of bills

- Possibly some consumer protection programs

A strong interest in social sustainability is expected to lead the government to establish minimum service standards dealing with power quality and customer service and to develop consumer protection programs, in order to protect electricity users' quality of life on an ongoing basis. Government also is likely to address the issue of stranded commitments, with an eye to ensuring the long-term viability of the utility industry. Some additional energy efficiency programs, renewable energy resources, and pollution reduction technologies also might be provided directly by government agencies, in the interest of ensuring a secure long-term energy future and minimizing adverse environmental effects. Additional low income programs are likely to be provided because social sustainability involves a heightened concern with protecting the quality of life for all 
strata of society. Specifically, weatherization efforts and a winter moratorium on service cut-offs are likely to be established, and programs to directly pay the bills of low-income customers also might be developed.

In this case, fewer actions are expected to go undone than in any of the other cases discussed previously. Some low-income programs-specifically the direct payment of utility bills for needy customers-might not be provided, and some consumer protection programs could possibly go undone. All of the objectives associated with economic progress, environmental stewardship and, of course, social sustainability, are expected to be met in this case. And, to a very large extent, all the objectives associated with social equity also would be met, although the protection of human welfare and the equitable sharing of costs and benefits could be compromised slightly.

\subsection{Trade-offs}

The above discussion shows that no single-value alternative results in all broad actions being taken or all value-related objectives being completely satisfied. An emphasis on any single value causes some actions to be emphasized and others to be downplayed or overlooked. When economic progress is the primary motivation, many of the objectives associated with social equity, environmental stewardship, and social sustainability are not met-or are met only minimally-as a result. Where the value of social equity is dominant, all economic progress objectives will continue to be met; however, the satisfaction of two key objectives associated with social sustainability would be diminished slightly and-most seriously-the ability to meet environmental stewardship objectives would be seriously compromised. Conversely, when environmental stewardship is held most dear by state regulators, the extent to which some of the objectives associated with social equity and social sustainability are met is reduced somewhat. In comparison to the other cases, the fewest actions are expected to go undone where social sustainability is the most important value; in this case, all economic progress and environmental stewardship objectives are expected to be met completely and the social equity objectives would probably also be satisfied to a large extent.

This brief examination of the trade-offs associated with each single-value approach suggests that, by explicitly holding multiple values and acting strongly in support of them, state regulators could avoid sacrificing the achievement of some key objectives in favor of others, as is generally the case when a single value is emphasized over all the rest. And, in fact, multi-value approaches tend to be the rule in the real world, although the importance attributed to each value-and the willingness to actively support them-vary considerably from state to state. The arrangements proposed in the following Section are driven by multiple values and represent a novel approach to satisfying key public policy responsibilities. 


\subsection{NEW IDEAS FOR SATISFYING PUBLIC POLICY RESPONSIBILITIES}

This section builds upon the discussions in Sect. 3.0 by moving from a short-term perspective to a long-term perspective. Presented below are numerous ideas, some are new and some are variants on existing ideas, that when taken together offer a path to satisfy all of four of the overarching public policy responsibilities outlined in Section 2.0. This discussion takes as given the basic retail competitive industry scenario structure that features separate generation, system operation, transmission, and distribution entities. This assumption should not be seen as an endorsement of this scenario or even suggest that the benefits of this structure, as compared to other structures, are well understood. However, many believe that retail competition is the future of the electric industry. Thus, for the exploratory purposes of this section, it is appropriate to assume retail competition in its most radical form as the setting for new ideas on meeting public policy responsibilities.

The first five parts of this section introduce five new institutions to augment the basic retail competition scenario. The word 'institution' is being used in a very broad sense. Bellah et al. (1992) explain that institutions are simply patterns of expected human behavior which are enforced by both positive and negative social sanctions. Waving good-bye is very simple institution given this definition. No law exists to force people to wave good-bye to each other, but it would be impolite in certain situations not to do so. Markets are also human institutions, as are corporations, electric utilities, and state and local governments. Each embodies an expected script of human behaviors that are designed to achieve specific means and ends.

New institutions do not necessarily have to impinge on individual freedoms, although many do in order to reduce externalities, and new institutions do not necessarily have to be embodied in new forms of government and government intervention. In fact, new institutions may at times be needed to complement market institutions and foster efficiencies in achieving goals. Seen in this light, electric industry restructuring is a process where the institutions associated with vertically-integrated, highly regulated electric utilities, such as the formal integrated resource planning process, are being replaced with new institutions, such as independent system operators and power pools and privately-owned distribution-only companies. The five new institutions presented below are designed to complement the operation of market institutions in the future industry while also acting toward meeting other overarching policy values.

One new institution is a regional board of directors to oversee system service organizations and transmission service organizations, and act as a focal point for other institutions and activities mentioned below (Sect. 4.1). A second element is the requirement for electricity franchises (Sect. 4.2). A third is the creation of computer-based siting marketplaces for new electricity facilities (Sect.4.3). A fourth is the establishment of electric industry foresight councils (Sect. 4.4). The fifth new element relates to the establishment of an electric industry coordination service (Sect. 4.5). 
In addition it is proposed that existing government institutions be mostly responsible for important energyrelated social programs (Sect. 4.6). Revenue sources for public policy initiatives are identified and are tied to several levels of government (Sect. 4.7). It is argued that franchises and electricity brokers be institutionalized in manners to assist in the achievement of public goals (Sect. 4.8). Overall, one can argue the approach could meet the four overarching goals and associated objectives (Sect.4.9), although it is clear that there are challenges to implementing many of the ideas set out in this approach (Sect. 4.10).

\subsection{Regional Board of Directors}

Increasing retail competition in the electric industry will reduce the ability of state regulators to control electricity systems in their states. Every type of electric industry company will seek to compete in as many markets as their business strategies dictate, whether the markets are located in their traditional states or in other states around the country. States will find it difficult to regulate footloose companies and multi-state markets (e.g., because utility-level IRP will be more difficult or impossible to implement), and the remaining monopoly services, especially transmission services, without cooperating with neighboring states.

Thus, the first institutional innovation to be considered is the Regional Board of Directors (RBDs), see Figure $1 .^{1}$ The mission of the RBD is to oversee interstate issues and monopoly services in an electric industry characterized by retail competition. As such, the RBD's major responsibility will be to oversee regional system service organizations (SSOs) and transmission service organizations (TSOs). The former will control dispatch and system operation to meet the difficult challenge of balancing economic and contractual obligations with the physical realities of modern power systems. The latter will own, build, operate, and maintain the transmission system. The RBD may also help to organize and resolve conflicts related to awarding electricity franchises in cases where franchises are multi-state in nature (Sect. 4.2). In addition, the RBD may have responsibility for implementing and administering several of the other new institutions introduced below, such as siting marketplaces (Sect. 4.3), foresight councils (Sect. 4.4), and the Coordination Service (Sect. 4.5).

The RBD will be lead by people appointed by the cooperating states. Strong consideration should be given to appointing state PUC commissioners to serve on the RBD. In this way, RBD decisions can be implemented through the existing powers of the individual state PUCs, thereby reducing the need for new legislation. The RBD will have resources to conduct analyses and support activities such as those mentioned above. The RBD should be supported by a state-level universal distribution or all-fuels charge.

\subsection{Franchises}

Figure 1 also depicts the basic retail competition scenario, as characterized by: separate generation, system operation, transmission, distribution functions; energy service organizations; electricity brokers; and the 


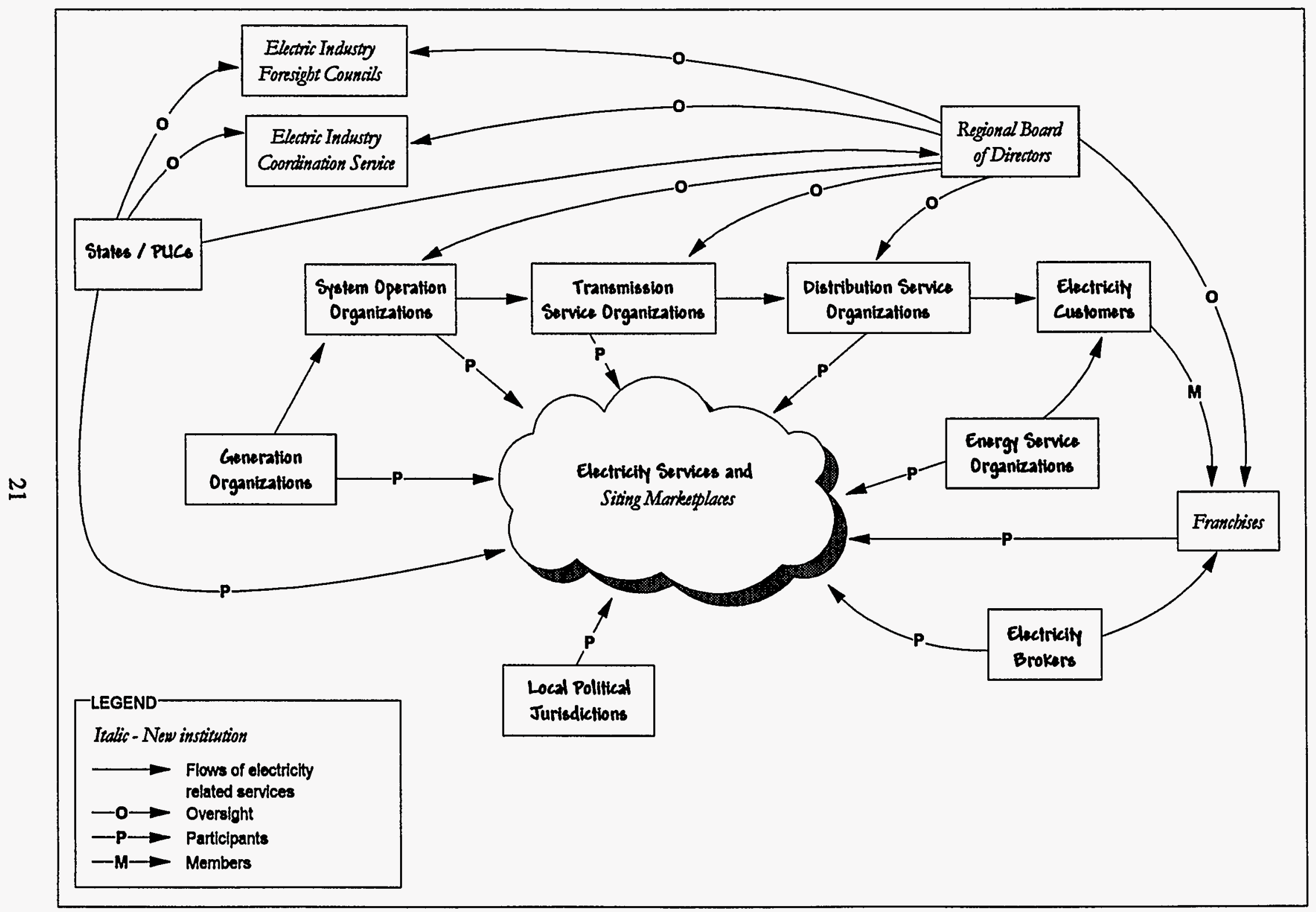

Figure 1. Retail competition with new institutions. 
second new institution proposed herein, electricity franchises. These are local or regional entities that manage electricity service acquisitions for their members. ${ }^{2}$ Specifically, franchises would be awarded by PUCs and would have the legal authority to: (1) sign contracts for electric power services for its members, through brokers or directly in the electricity marketplace; (2) purchase other electricity services, such as DSM; (3) impose electricity-related regulations, in conjunction with regulations imposed by governments (see Sect. 4.7); and (4) raise revenue for and implement their own electricity-related social services (again see Sect. 4.7).

In addition to not owning substantial electric power technologies, franchises would be different from today's municipal and co-op utilities in other ways. Franchises are not envisioned to be municipally-owned, but rather owned by members who are electricity consumers. ${ }^{3}$ Franchises are also not envisioned to be power brokers or aggregators. If awarded according to criteria mentioned below, customer ownership of franchises avoids the need to require broker-based franchises to serve prespecified percentages of at risk customers. To provide maximum flexibility, franchises may be spatially diverse or even non-spatial in nature (e.g., an industrial franchise may include members scattered throughout a large geographic region). ${ }^{4}$ Because franchises do not have to be created coincident with any political boundaries and may even encompass several states, RBDs may have to be involved in their construction and award. Lastly, unlike municipals and co-ops, it is not envisioned that franchises would own generation or distribution systems, although it is possible that franchises might invest in very small scale generation technologies, such as roof-top photovoltaics

Under this approach to franchises, every electricity customer must be a member of an electricity franchise. State PUCs, or RBDs, will award franchises and oversee the creation, change, and dismantling of franchises. A potentially cumbersome challenge for the PUCs or RBDs is to insure that the franchise plan ensures mutual exclusivity (no customer could belong to more than one franchise) and exhaustiveness (all customers must belong to one franchise). Another challenge is to oversee the process to ensure that each franchise is large enough to: have the ability to negotiate with power brokers on equal footing; allow for members within the franchise to set and implement meaningful electricity-related policies; and be an institution which can be a focal point of government policies (e.g., related to portfolio standards). Lastly, the franchises need to be designed with equity in mind, to avoid 'cream-skimming' and the 'provider-of-last-resort' problems.

Admittedly, this franchise proposal is at odds with proposals for retail competition where each individual customer has complete autonomy over electricity purchases. Pertinent questions are: how can the franchiseconcept be made more consistent with this vision; what is gained from some loss of consumer autonomy; and why are power brokers/aggregators and franchises both needed? With respect to the first question, franchises will be able to act in the market and negotiate contracts that could contain requirements that are very detailed to very specific members of the franchise (e.g., through the idea of full-service or one-stop shopping contracts). In addition, franchises could be constituted in ways that group customers who share market preferences (e.g., residential franchises, industrial franchises). Also, the certain knowledge that a customer 
will benefit from the buying power of a franchise as opposed to the uncertain buying power of belonging to unmanaged broker pools or to no customer group at all would go some way toward overcoming the loss of some economic choices related to purchasing electricity services.

As noted above, franchises could still use power brokers or aggregors as their representatives in the electricity marketplace. Some franchises may prefer to use brokers rather than keep such expertise on their staffs. In addition, it is possible that power brokers will be able to aggregate several franchises across several states if not several regions for the purpose of bidding for power and other electricity services. Brokers themselves may become very specialized, to the degree that a franchise may contract with different brokers for different types of services. Thus, postulating both franchises and power brokers is consistent with the goals of consumer choice and institutional flexibility.

A major argument for franchises is that they contribute to the institutional framework for satisfying social equity, environmental stewardship and sustainable society values. With respect to social equity, franchises themselves could implement customer protection and other fair-trade safeguards, low income weatherization programs, and minimum service requirements. Alternatively, or in addition, states, through their PUCs or other agencies, could stipulate that certain types of franchises provide these types of programs as a condition for the award of a franchise. Presumably, states would be more likely to impose such stipulations on a nonprofit type of entity than upon a private sector firm, such as a distribution company. If franchises are awarded to cover the entire customer base, then the problem of who would be the electricity provider of last resort would be a non-issue.

With respect to environmental stewardship, again the franchise would be an institutional entity for states to use to implement such programs as DSM, and renewable energy portfolio standards, which are hard to implement if no entity in the restructured industry wants or can reasonably be regulated to undertake these tasks. Of course, franchises could also decide to pursue such programs on their own and one could reasonably expect that they would implement IRP principles to help guide their decision making. Lastly, with respect to social sustainability, well-constituted franchises could help foster a sense of community, especially if ownership and management structures promote membership participation in franchise decisions. It can be argued very persuasively that public participation in franchises is a fantasy, given widespread apathy in the current U.S. electorate and various other constraints to public participation. The reply with respect to franchises is that apathy is not necessarily a permanent condition and that it is worth every effort to design new institutions to promote public participation.

\subsection{Siting Marketplaces}

A second major difference between our approach and the typical retail competition scenario is the inclusion of siting marketplaces (shown in conjunction with the electricity services marketplace in Figure 1). Specifically, 
siting marketplaces will assist in siting new electricity-related facilities, such as power plants and transmission lines. Participants in siting markets include: generation companies, transmission companies, distribution companies, local political jurisdictions, electricity franchises, and states. A national siting marketplace would be funded by a national transmission tax, overseen by a federal government organization, and built and operated by a national-view organization, such as a major non-profit organization. Another alternative would be to have regional siting marketplaces overseen by the RBDs and funded by state-level universal distribution charges. It is conceivable that the best alternative would encompass both a national scope siting marketplace and more specific, regional issue marketplaces. It is not likely that new legislation would be required to create siting marketplaces that are under the purview of existing agencies.

The purposes of a siting marketplace are to improve the exchange information and make more efficient negotiations about siting proposals. In such marketplaces, what are traded are obligations among parties to accomplish certain actions, to provide specified resources, to accept various risks and ultimately to allow siting of facilities in specific places at specific times. An effective siting marketplace would include more people in the important discussions, consider more potential options than is accomplished in the typical muddling through approach, and reach decisions that more often would approach pareto efficiency.

A siting market would operate something like this. An intention to build a new plant or line would be posted in the marketplace (most likely an electronic entity built upon the capabilities of the Internet) by a generation company or transmission service organization, for example. The notice would provide general outlines of where the plant or line could be or needs to be located, along with other pertinent technical information. The notice would request preliminary interest from local political jurisdictions, franchises, and/or states about hosting the new project. Indications of preliminary interest would include initial financial and other criteria that the firm might have to meet to locate its facility in the locality/state.

For desirable facilities, the siting marketplace would pit franchises/localities/states in competition for the facilities. For undesirable facilities, the marketplace would need to facilitate the transfer of resources from places that do not want to host the facilities to the places that might only grudgingly accept the facility if it were financially worth their while. For example, if community A indicates that it might accept a new transmission line only if it received $\$ 2$ million per year for 20 years to support local government, communities $\mathrm{B}$ and $\mathrm{C}$, which might be the only other two logical hosts for the new transmission line, might be willing to negotiate to provide $\$ 1.5$ million. Community A may come back with a revised offer of $\$ 1.7$ million. (An Internet-based system would be able to provide the communications services required to foster such negotiation and coalition building). Whatever the path of negotiation, a siting marketplace will only succeed if it allows different players to collaborate in multi-party offers (e.g., from many jurisdictions in the path of a proposed transmission line) to bring together builders and potential hosts of new electric facilities. 
Among many vexing issues associated with this idea are the role of existing siting authorities and laws, potential destructive competition among the states, and management of the marketplace. With respect to the first issue, it is incumbent for state siting authorities to take an active role in the marketplace, whether the agency be a state agency or the PUC. Proposals made by potential hosts with approval of siting authorities will be much better received, and will be more beneficial to the hosts, than proposals made contingent upon future siting approvals. A siting marketplace will not usurp state laws nor eliminate the power of eminent domain. Its major contribution will be to increase communication and facilitate economic trade-offs to reduce the need for states to unilaterally use their powers to site new electricity facilities.

With respect to the second issue, states are currently engaged in a very destructive process in trying to attract from other states new industrial facilities that will provide new jobs. Unfortunately, inducements such as property tax and income tax reductions, have the potential to reduce severely local and state tax bases needed just to provide basic governmental services. Might there be such competition for electricity generation facilities and might a siting marketplace just foster more destructive decision making? These are questions that require serious consideration and ought to be confronted whether or not formal siting marketplaces are established. ${ }^{5}$

Lastly, a sophisticated, electronic siting marketplace is no guarantee that in the end, a siting decision will be made. As indicated below, one of the roles of the Electric Industry Coordination Service would be to manage the negotiation process to be implemented through the marketplace. It may also be that in certain instances, localities, states, and even the federal government may have to step in an impose a solution in order to site a desperately needed facility whose siting has become bogged down in negotiations. Of course, threats of such unilateral government actions may be part of the siting negotiation process.

\subsection{Electric Industry Foresight Councils}

The disintegration of the utility-based electric power industry will bring with it the loss of some or all of the integrated resource planning functions carried out by vertically-integrated utilities (Hirst, Tonn, and Bauer 1995). It is unlikely that states will desire to replicate IRP-type programs or be successful even if they try (see Sect. 2.0): However, IRP is a powerful concept with respect to satisfying public policy responsibilities because it offers a community perspective framework to consider systemic problems, equity issues, environmental issues, and external threats. Electric Industry Foresight Councils (Councils) are envisioned as a means of replacing IRP with an institution that promotes the development of a community mind set that could form the basis for integrated but self-directed behaviors aimed at satisfying community goals (Fig. 1).

Generally, the Councils will accomplish this by serving as forums for multiple constituencies to discuss the future of the industry from multiple viewpoints. Council members should include generators, system 
operators, transmission service organizations, distribution service organizations, energy service companies, franchises, governments, non-governmental organizations, and other private sector organizations. Important issues for discussion include regulatory reform, environmental issues, other public policy responsibilities, and national and international competition. Research and analytical organizations could present forecasts and speculations about the future. For example, one can speculate that important new public policy issues will arise concerning: customer privacy, which could be at question as distribution companies improve their monitoring of electricity use and as houses get smarter; computer security, which is already a major problem but could become even more worrisome as industry players and markets become ever more networked; and terrorism/system security, which is already a major problem in countries such as Peru where insurgents regularly target the electricity infrastructure. The Councils will be a place for people to network and nurture collaborative relationships.

Figure 2 illustrates one potential process implementation of the Councils. To begin, there are two types of Councils, a National Council (administered by a collaboration between DOE and NARUC, for example) and Regional/State Councils (to be administered by the PUCs and other pertinent state regulatory bodies, such as RBDs). The Councils would not institute formal hearing processes that create an atmosphere of hierarchy and contention among special interests, which is why they must be separate from existing regulatory institutions. Instead, the Councils would institute an open-framework and participant dialogue process to tackle important issues.

The first step entails foresight. The foresight process would begin by having the administering organization(s) pose questions about the future to the members of the Councils, possibly based on inputs from researchers, policy analysts, and others. The administering organizations would help provide data and information to help inform the deliberation process, although it would be expected that much data and information will be publicly available in any case (e.g., in the form of government statistics and forecasts and research findings and reports). After due consideration, the Councils' members would provide expressions of foresight with respect to the posed questions. The administering organizations would aggregate the answers and distill these data into information useful to Council members. This process would be encouraged to be iterative in order to help achieve a Council consensus on the answers to the questions. Consensus methods can be used to create consensus statements on forecasts and policy issues if group aggreement cannot be achieved otherwise.

After a consensus is achieved, the administering organizations would pose a second set of questions regarding what should be done to overcome the problems identified during the foresight process. Again after due consideration and iteration, a consensus on general responses may be reached. If reached in a credible and open manner, it can be expected that the various levels of government will feel some obligation to act on these recommendations. In as far as these government responses do not directly impact the private sector, firms will be left to their own devices to set their corporate strategies in light of general threats and 


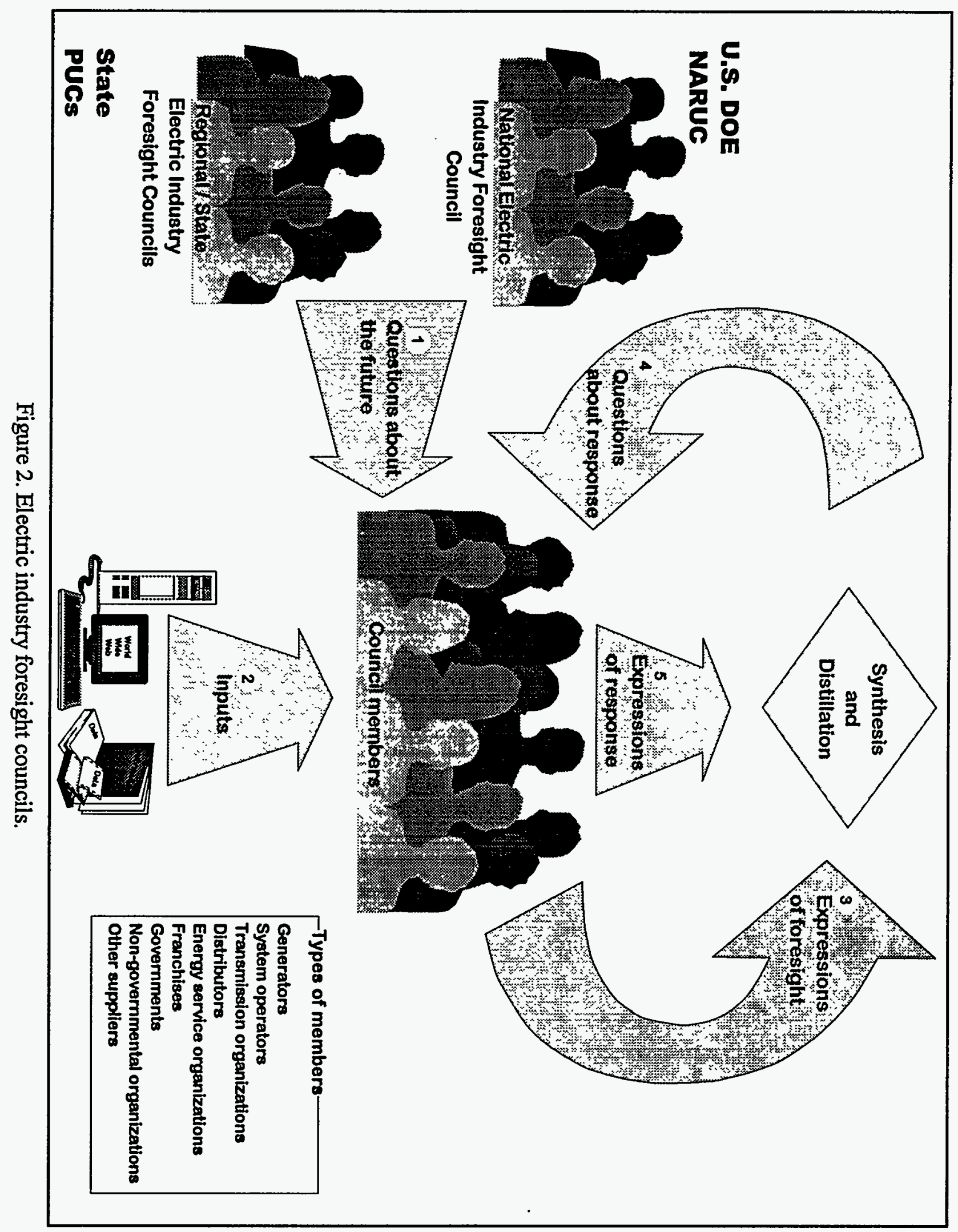


opportunities unveiled during the discussions. Overall, this process of questioning, deliberation, and consensus about the future and associated responses will substantially result in a community mind set on threats and actions needed to maintain progress toward important goals. ${ }^{6}$

It is recommended that funding for the Councils come from a national transmission charge (for the National Council) and state-level distribution charges (for state/regional Councils). If DOE/NARUC and existing PUCs and/or RBDs managed the Councils, it is unlikely that new legislation would be needed for their implementation. It is also recommended that the major players in the electricity industry (i.e., generators, system operators, transmission service organizations, distribution service organizations, and franchises) be required by PUCs to participate at least in the state/regional Councils.

At least three serious potential problems with the Councils concept should be addressed. Two problems eminate from worries about competition. The first problem stems from a potential lack of desire of firms to participate in the Councils for fear of divulging corporate strategies and intelligence. The second problem stems from firms participating too earnestly and closely, such that anti-trust concerns may arise. Neither of these problems should surface in a properly run Council, where general issues related to electricity supply and demand and environmental and other issues will be discussed. The goal is to elicit thoughts about trends and general responses, not what each firm's plans are in the coming years.

The third problem relates to the lack of 'teeth' given to the Councils. The only power suggested that the councils have is to require that certain types of organizations participate in the discussions. This is only reluctantly suggested and may be difficult to implement in any case because PUCs and other related agencies do not have jurisdiction over most of the potential participants. In any case, without any substantive legal authority to make people do things, can the Councils be successful? The answer is yes, and hinges on what is meant by an institution. If people accept that an institution is valuable in their lives, if people behave in manners within the institutional setting to make the interactions efficient, and if informal social norms arise that penalize people for not participating, or participating inappropriately, or behaving afterwards in ways incongruent with the themes of the institution, then the institution can be considered as having influenced human behavior, with or without legal perogatives. Given these conditions, there are no unsurmountable barriers to the success of Councils. Indeed, people may enjoy the opportunity to participate in an institution where public/private sector antagonisms and legalities are left outside the door.

\subsection{Electric Industry Coordination Service}

The Electric Industry Coordination Service (Service) is envisioned to be the ombussman for the electric industry (Fig. 1). It would have two major responsibilities. First, the Service would manage alternative dispute resolution (ADR) for the industry. As explained by Coughlin (1995), ADR will be increasingly needed in a disintegrated industry as situations for disputes involving contracts and the establishment and 
management of regional transmission groups multiply. It is added that the Service would also help resolve disputes related to the satisfaction of public policy responsibilities, the establishment and demarcation of franchises, and interjurisdictional political disputes. These disputes will arise bilaterally and multilaterally and can involve a large range of players. It can be persuasively argued that in many instances, ADR can save enormous time and money that is often involved in taking disputes to court.

Second, in addition to being reactive, the Service would also be proactive. One of its responsibilities would be to envision collaborations among electric industry constituents that may enjoy the benefits of scope and scale and that are consistent with the judgments of the Councils. ${ }^{7}$ Another responsibility would be to identify potential points of conflict among the goals and intentions of electric industry constituents in order to reduce potential conflicts even before ADR may be required. For example, the Service could identify franchises that might be able to collaborate in the acquisition of electricity services and identify franchises whose plans may conflict with each other.

The Service could be particularly effective in coordinating the siting of new generation plants and transmission lines, in conjunction with activity in siting marketplaces. For example, it would be especially challenging to manage complex coalitions needed to make bids associated with the new construction of long transmission lines. Lastly, the Service would assist the Councils and other participants in the electricity industry deal with uncertainty and engage in learning activities. The Service could accomplish the last goal by collecting data and information in real-time on major electric industry decisions and activities for evaluation and retrospection at a later date, possibly as part of the Councils' deliberations.

Given this description of the roles and responsibilities of the Service, the Service would complement the franchises and Councils with respect to accomplishing the spirit of IRP without having a formal IRP process. Instead of developing and implementing a 'plan', which would be very hard to do since no one organization controls all the pieces in a deintegrated industry, the Councils would ensure that every player has the opportunity to share discussions and develop common beliefs about the future of the electric power industry and public policy responsibilities, the Service would foster cooperation among the organizations so that their ever-shifting goals, intentions, and behaviors mesh together in mutually-satisfactory manners, and the franchises would be a logical point of focus for the implementation of IRP principles. The entire structure also provides mechanisms for mid-course corrections and pathways for government action in times of crisis. For example, if global climate change becomes a crisis, as some already think, then this issue can be discussed at the Councils, the various legislatures can pass emissions-related programs and possibly impose portfolio standards and other measures on the franchises. The Service would be available to help mediate and arbitrate disputes related to emissions tracking and reporting, for example, and assist franchises in working together to collectively meet regulatory mandates. 
The Service would be funded by the federal transmission tax and state distribution taxes. The federal and state governments, and possibly the RBDs, would oversee and administer the Service. In a reactive mode, the Service would approach dispute resolution according to rules agreed to by the disputants (e.g., mediation versus arbitration) or predetermined rules that apply to specifically defined problems. In a proactive mode, the Service would have wide latitude in identifying collaborative opportunities among electric utility constituents. However, the Service should only be allowed to act as an idea generator and advisor. One reason is that good ideas for collaboration would be expected to be voluntarily embraced by the appropriate parties, making a legal imperative unnecessary. Second, endowing the Service with such legal authority would needlessly interfere with the ability of the Service to impartially carry out its ADR responsibilities. Last, politically it would be unwise and untenable to empower a new agency with additional regulatory powers.

\subsection{Government Responsibilities and Programs}

In addition to considering new institutional arrangements, it is important to explore innovative and other significant actions that existing government institutions can undertake to help achieve public policy goals. Table 8 contains a list of suggested government responsibilities and programs that contribute toward meeting the four overarching values discussed in Sect. 2.0. Associated with each program description is a locus of government authority. In many instances, more than one entity needs to be involved in providing the service, with different entities taking the lead and providing supporting roles, depending on the service. This section contains a short description of each program and why it is useful.

Long-term, high risk, high payoff research and development. It has long been recognized that the nation benefits from a R\&D system where, in general, the responsibility for basic and long-term, high risk, high payoff R\&D rests with the federal government and applied and short-term, quick pay-back research rests with the private sector. Debates have raged recently over where to draw the lines between these two areas and whether to more formally connect them via cooperative programs. The debate until recently hasn't focused extensively on the electricity industry, because the regulatory environment promoted relatively successful privately-sponsored basic and long term research. ${ }^{8}$

As competition has increased, the profile of electric industry $R \& D$ is changing to resemble the $R \& D$ profile of most other major technology-based industries. Specifically, the electric power industry has begun to reduce its R\&D expenditures and shorten time horizons. As a bellwether, Electric Power Research Institute programs are becoming more narrowly focused on short-term issues and challenges. In response, the federal government needs to continue to support R\&D in such areas as renewable energy, fusion energy, superconducting transmission lines, materials science, human health, environmental protection, and advanced energy efficiency designs. These can be viewed as basic research and very long-term efforts. 
Table 8. Specific government programs and responsibilities*

\begin{tabular}{|l|l|}
\hline \multicolumn{1}{|c|}{ Program Description } & \multicolumn{1}{c|}{ Locus of Authority } \\
\hline Long-term, high risk, high payoff research and development & Federal \\
\hline Efficiency standards & Federal/state/franchise \\
\hline Foresight and policy analysis & Federal/state/franchise \\
\hline Emissions caps and taxes; other environmental regulations & Federal/state/franchise \\
\hline Model Systems Program & Federal/state/local jurisdiction/franchise \\
\hline Minimum service standards & Franchise/state \\
\hline ISO standards & Industry/federal \\
\hline Integrated energy services & Federal-state-local jurisdiction-franchise \\
\hline Collaborative electricity services program & Franchise-industry/state/federal \\
\hline Portfolio standards & $\begin{array}{l}\text { Franchise/state/federal \{no crisis } \\
\text { Federal/state/franchise } \text { \{crisis situation\} }\end{array}$ \\
\hline Economic regulation & State/federal \\
\hline
\end{tabular}

* Locus of authority moves from left to right after /s. Equal authority denoted by -s.

Efficiency Standards. Efficiency standards should continue to be set, assessed, and revised to help protect the environment and husband non-renewable resources. Efficiency standards offer a direct and relatively certain method for reducing energy use and emissions (e.g., as opposed to taxing energy use and emissions, which may or may not lead to emissions reductions depending on whether one wants to pay the tax or not).

Efficiency standards can be viewed as a no-regret policy because it provides the stimulus to continue to improve products and technology, to maintain a pace of innovation that will support US industry vis a vis international markets. Efficiency standard setting needs to be realistic and done in conjunction with federal R\&D program planning and technology transfer activities. The federal government should take the lead in standard setting to provide continuity throughout the nation, with states and even franchises being able to custom design standards as appropriate.

Foresight and policy analysis. Foresight and analysis are attributes of intelligent behavior. These activities help to identity possible threats and risks and evaluate appropriate responses to such situations. Because of the importance to the US of the electric industry and its complexity and potential for tragedy of the commons types of problems (e.g., depletion of a regional water supply, depletion of national energy reserves, general breakdowns in providing electricity services that may arise not due to irrational behavior on the part of individual customers and suppliers but do to negative feedback loops in the entire system (see Senge 1990\}), the federal government needs to take a lead role in fostering and implementing foresight and policy analytic activities. States and franchises should also conduct more focused analyses that are tailored to their own 
needs. All these activities need to feed into the discussions of the Councils. It should be stressed that foresight and analysis does not necessarily lead to additional regulation and government action. It is hoped that the collaborative nature of the Councils could allow for cooperative behaviors to overcome identified problems. On the other hand, not engaging in foresight and analysis will certainly expose current and future citizens, companies, and the environment alike to untoward and potentially catastrophic and unnecessary risks.

Emission caps and taxes; other environmental regulations. As discussed in Tonn, Hirst and Bauer (1995), it is unlikely that the private sector will reduce emissions and otherwise implement actions to protect the environment without government intervention. Theory and growing data indicate that more flexible performance-based standards are more cost-effective than command and control regulations. Thus, emission caps and emission taxes are the favored mechanisms to reduce air and water pollution. However, other types of regulations are still needed in many instances (e.g., related to coal mining, waste disposal, energy use). The federal government needs to take the lead because pollution is largely multi-jurisdictional (and multi-national) and because to gain economic advantage, some argue that some states may lower (and are already lowering) their own environmental standards.

Model Systems Program. There is a paucity of innovation at the community level with respect to providing electricity and other services. There are very real opportunities to build 'model systems' that integrate electricity services, transportation, housing, work, retail services, education, and advanced computer-based systems and information infrastructures. For example, one-stop shopping systems can be developed to provide citizens with coordinated access to the integrated services mentioned below, personal digital assistants can allow people to communicate in real-time with energy appliances in their homes, neighborhood telecommunication centers could offer broadband and computing capabilities to support work, shopping and education while helping to reduce transportation energy use. It is impractical for the industry to fully fund many of these kinds of projects because they cross-industries and may require involvement of the participating franchises and local political jurisdictions. On the other hand, it would take only a few successful projects to illustrate the innovative potential of new technologies and suites of services. Modeled after current grant programs, the federal government could award grants to states, local political jurisdictions, and/or franchises to design, prototype, implement, and evaluate innovative model systems programs. Participating agencies could include, but not be limited to, DOE, Department of Transportation, Housing Urban Development, Department of Commerce, Department of Labor, Environmental Protection Agency, and Department of Education.

Minimum service standards. State and federal regulators should continue to specify minimum service standards that cover such areas as public safety, technical specifications for power quality at the customer's meter, consumer protection, and customer service. Customer protection and service requirements should be imposed upon the franchises and the electricity brokers. Public safety is everyone's concern. Generation, 
transmission, and distribution companies will need specific standards related to system reliability and power quality. As noted immediately below, the private sector should be encouraged to set its own standards.

ISO standards. The International Standards Organization (ISO)-not to be confused with independent system operators, which we refer to as system service organizations - claims among its member numerous national standards organizations. This organization meets and issues standards on many topics. Recently, this organization issued ISO standards, as they are called, related to product production quality. These standards are gaining acceptance worldwide. Set with the assistance of industries themselves, the standards provide one means of promoting quality assurance. The idea is for the electric utility industry to develop and adopt their own standards and certification procedures, for example related to providing transmission and distribution services. Federal involvement would only be needed, possibly through the Coordination Service, to mediate/negotiate standards that have international implications. Successful implementation of ISO requirements will render as superfluous many of the technical minimum service standards imposed by state and federal regulators.

Integrated energy services. Traditionally, social programs associated with the provision of electric services have been mainly funded and implemented by the utilities, or in some cases, as programs separate from other social service programs. The highly regulated, vertically integrated utility was a rational choice because it had access to those people requiring services, the cost of the programs could be built into the rates, and PUCs could require utilities to provide the services. In a competitive industry, players engaged in competition have little incentive to spend large sums of money on social programs and to a degree, it should not be expected of such firms. Deintegrated transmission and distribution companies will have less financial resources and less binding ties to the old social contract. However, this situation opens up the opportunity to integrate the provision of energy services across governments and the franchises (see Figure 3), such as by synthesizing housing and low income weatherization programs. Providing affordable housing to cohorts of low income families over time may be optimized by developing programs that both support low income families ability to buy housing and by reducing the cost of renting and 'operating' housing. Consolidated bureaucracies and onestop shopping service delivery, assisted by advanced computer-based systems, could also cut costs and act to rationalize service delivery. All levels of government, including the franchises, have equal responsibility for integrated social services.

Collaborative Electricity Services Program. In many sectors of the economy, the producer and the customer share in the production of goods and services, to the mutual benefit of both. Simple examples include selfservice gas, warehouse shopping, all-you-can-eat buffet restaurants, and even businesses that supply everything to wash your dog except the dog and the person to wash the dog. Granted, these collaborative economic efforts are not very sophisticated but they do reduce costs to those customers who are willing to devote the time and effort. These ideas can be transferred to the delivery of electricity services and negotiated as part of the franchise contracts. Ideas to consider include: having local residents regularly inspect nearby 


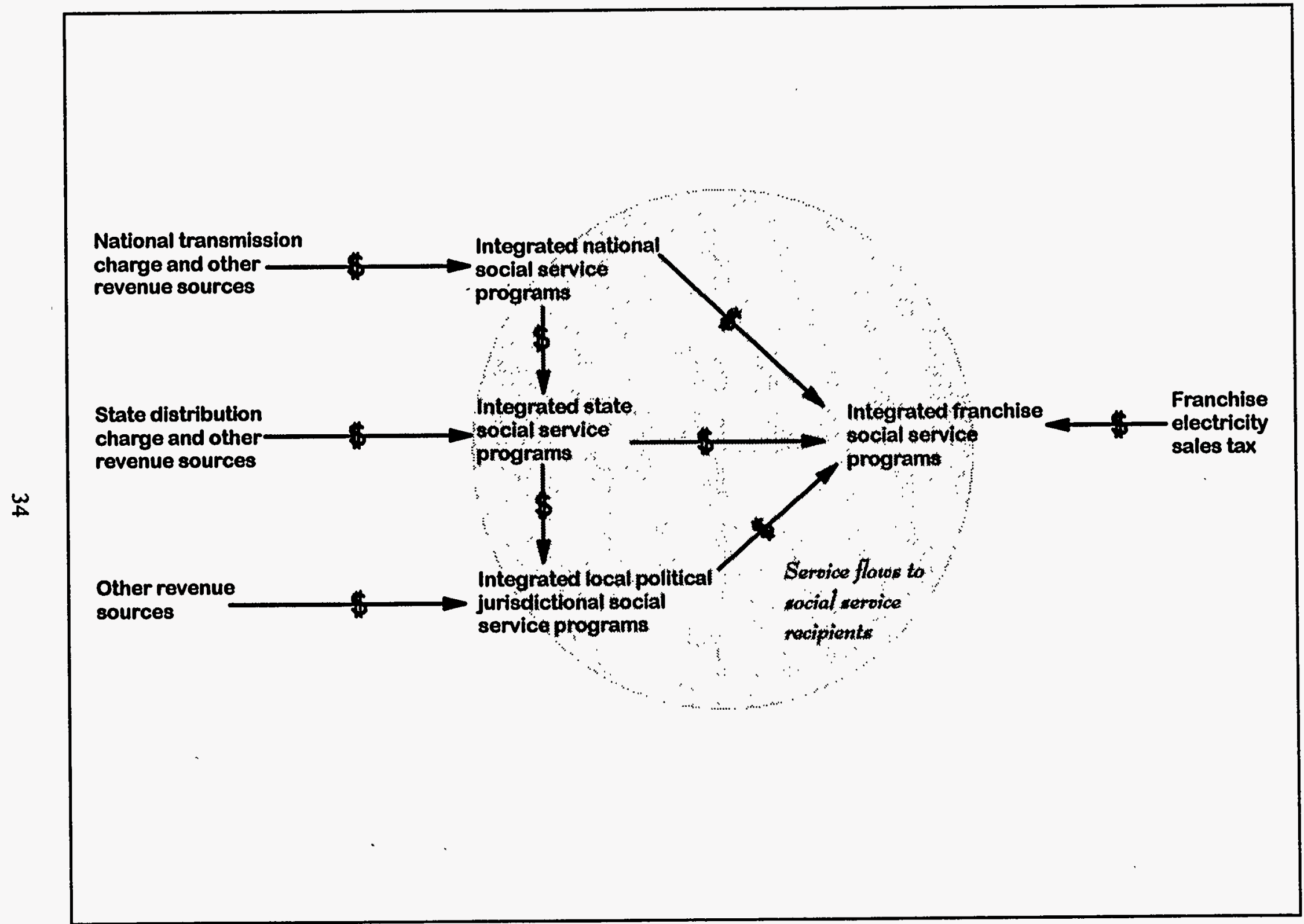

Figure 3. Providing integrated social services. 
poles for wear and tear; install and operate mini-generators as directed by the system operator; voluntarily collect data vital for system operations and potentially useful for system planning (e.g., on wind in specific locations, use of end-use technologies); and maybe even undertake tedious but easily taught pattern recognition tasks (e.g., inspecting $x$-rays of pipes for cracks).

Portfolio standards. It is very premature to abandon renewable energy technologies at this point in time. Events could quickly change (e.g., an unexpected interruption in oil supplies) and these technologies need to be readily available. Even more important, people need to have knowledge about these technologies and experience in building, operating and maintaining these technologies in real-world settings. Because everyone, including future generations, benefits from this conservative strategy, and to eliminate free-riders, portfolio standards should be implemented at the franchise level and made part of franchise IRP-type activities, with coordination between states and the federal government. If there is a crisis, such as a strong and persuasive confirmation of global warming and potential catastrophe, then the federal government should take the lead in specifying the portfolio standards for renewable energy sources.

Economic regulation. The federal government and states will continue to have responsibility for overseeing the various markets and players in the electric industry. Monopolies in the form of transmission companies and distribution companies will still require regulation of tariffs and access, and oversight. Consumer protection practices and fair trade laws will need to be applied to the industry as well.

\subsection{Revenue Sources for Meeting Public Policy Responsibilities}

A simple approach is proposed to financing the programs and activities outlined in this section. There are three major sources of revenue, each tied to a different level of government: a national transmission charge to support federal programs; a state universal distribution charge to support state programs; and a sales tax at the franchise level to support local programs.

The national transmission charge would support the a national siting marketplace, a national electric industry foresight council, federal electric industry $R \& D$, federal regulatory and policy analysis and setting activities, and the federal government's share of the costs for the Coordination Service and the Model Systems Program. The national transmission charge would be set by Congress and included in unbundled transmission rates regulated by FERC. The transmission system operators would remit the charge to the federal government.

The state distribution charge, sometimes also referred to as a universal charge or a non-bypassable charge, would support the Regional/State Foresight Councils, state-level regulatory and policy analysis and setting activities, and the states' share of the costs for the Coordination Service and the Model Systems Program. Within a state, the PUC, the state legislature, and other pertinent agencies would need to coordinate how the distribution charge would be set. For example, the PUC could set the charge as part of its rate setting and 
oversight of the distribution companies. On the other hand, the state legislature could decide on the charge in the same way that other revenue is raised. The distribution charge would be included in unbundled distribution rates and paid by the distribution companies.

One option to the state distribution charge would be a state-level all-fuels tax, such as exists in Vermont. The arguments for an all-fuels tax include: it would not discriminate against one or another fuel; and revenues raised could be used to support energy services that encompass all fuels, not just electricity (e.g., weatherization of gas or wood fuel heated homes). An all-fuels tax could easily support the Councils, the Service, and the Model Systems Program: One difficulty with broadening the tax to include additional fuels is that there might be corresponding expectations to broaden the scope of the funded services (e.g., broadening the scope of the Councils to include all fuels and of the Service to encompass the natural gas and fuel oil industries, for instance). On principle, broadening such discussions should be favored, to be more inclusive rather than exclusive. However, many decision makers are already facing difficult decisions and enormous pressures from competing interests just within the traditional confines of the electric industry. They will need to decide whether it is politically possible and beneficial to broaden the debate to the degree necessary to prudently consider an all-fuels tax.

Each franchise would need to raise revenue, at least to support its basic activities (e.g., contract negotiation, IRP-type activities). Also, as mentioned above, franchises would have the freedom to implement a broad range of programs and certain types of franchises may be required to provide certain types of programs, all of which will require financial resources. A sales tax would be decided by the franchise and paid by franchise members as part of their remittance to the franchise for electricity services.

This financing design has several positive points. One, each source of revenue should be seen as economically efficient, because each is based on volumetric versus fixed payment principles. Two, each level of organization is tied to a revenue source that is logically related to its regulatory and management responsibilities. Three, the revenue sources are non-overlapping and can be well-defined, which will minimize political jurisdictional disputes. Four, revenue raised from taxing the use of electricity is reinvested in the industry, which acts to minimize political disputes about what the money will be used for and how much to collect. Five, each tax is paid in incremental and relatively small amounts and does not require complex bookkeeping on the part of the taxpayer, which meets with less public resistance than lump sum property taxes and burdensome income taxes.

As a final point, additional thought is needed to evaluate the interactions among these three revenue approaches and the satisfaction of the four overarching values. For example, might the national transmission charge work against the goals of economic competition and efficiency? With respect to social equity, it is clear that without some other adjustments, the financing design is regressive. However, several kinds of adjustments are possible that can yield a progressive financing design. If franchises are created according to 
affinities (e.g., residential franchises, commercial franchises), then one can envision direct federal/state subsidies to low income franchises and differential distribution charges by franchise type. If franchises contain a mixture of electricity customer classes, then PUC's could require franchises to negotiate tiered electricity rates based on use and/or government(s) could directly subsidize low income customers. With respect to environmental stewardship, key issues center on how to relate the financing scheme to other taxes, such as emission taxes and national fuels taxes.

\subsection{Ownership, Reward Structures, and Other Considerations}

This subsection focuses on ownership of major electricity facilities and systems, and reward structures for major electric industry players. Related to the former, our general approach does not require specific types of ownership for generation, transmission or distribution entities. This is because entities owning these types of facilities do not have responsibility for providing social services or managing programs beyond their key responsibilities of providing generation, transmission, and distribution services, respectively. It is assumed that most generation will be privately owned (excluding federal government ownership of large hydro facilities, for example) and that transmission and distribution will continue to have a mix of public and private ownership. There are no barriers or objections to public ownership of generation, transmission, and distribution, other than considerations of economic efficiency and the ability of public entities to be able to focus adequately on the provision of electric services.

Privately owned transmission and distribution service companies should still be regulated by FERC, and PUCs or RBDs, meaning that PUCs and RBDs will be significantly involved in determining reward structures for these companies. We recommend the use performance based measures related to costs, service, reliability (Hill 1995). In addition, participation in foresight councils and siting marketplaces, cooperation with the Collaboration Service in setting disputes and setting ISO and minimum service standards, and contribution to model systems projects and the provision of collaborative services could also be considered as performancebased measures.

Ownership of the system operation organizations is a more difficult question. We can see arguments for public ownership (using an FAA model) and private ownership. As discussed in Sect. 4.1, the RBDs should have clear oversight of the SSOs. At this point in time, we are deferring this issue for future consideration.

Brokers play an important role in this approach. They can be formed as partnerships, non-profits, or corporations. They are responsible for delivering the services obligated in contracts they sign with the franchises. Some method is needed to reward good performance and penalize bad performance. Because brokers are not monopolies, it is unreasonable to require PUCs to regulate them. However, states and the federal government can enact laws which stipulate the types of contracts that brokers can offer to franchises. One approach is to stipulate that brokers only be allowed to offer award-fee contracts to franchises. A 
percentage of payments to the broker would be put into an award fee fund. The brokers are awarded fees based on meeting criteria in the contract, and the fee can be shared among the generation, transmission, and distribution companies as way of sharing risk. The criteria may include a diversity of items, including DSM, meeting portfolio requirements with respect to renewables, minimum service standards, and service price and choice. CPA firms would be tasked with the responsibility of performing the audits to determine the amount of the award. Unawarded fees can be cycled back to the franchise, expended on alternative programs to meet the award fee criteria, or even sent to state and/or federal treasuries.

\subsection{Meeting Overarching Values and Associated Objectives}

The ideas presented in this section have the potential to substantially meet the evaluation criteria set out in Sect. 2.0. The relationships between the four overarching values, thirteen objectives, and the various institutions and other actions presented above are represented in Table 9. Each overarching value is discussed below.

Economic Progress. Because our ideas are set within a full retail competition scenario, by definition this approach supports economic values related to efficiency, competitiveness, and customer choice. Economic progress can be supported in numerous other manners, too. For example, the siting marketplace, foresight councils, Coordination Service, and emission caps and taxes, can further catalyze economic efficiency. Each tax is related to electricity use, which has the least negative impact on economic efficiency. The flexibility of the franchise concept, electricity service contracts, and brokering arrangements can support competitiveness and customer choice. The broker fee upon satisfactory service provision can promote the efficient delivery of services and customer choice. The federal R\&D program and the Model Services Program can support new economic development and new products and services. These elements plus industry-adopted ISO standards can contribute to international competitiveness. PUCs and the federal government would continue to regulate the industry, especially monopolies in transmission and distribution, to protect efficiency and customer choice objectives. A strong foresight and policy analysis program can ensure that important economic trends and threats to economic progress are identified and that electric utility decision makers and the public have the best economic information for decision making.

Social Equity. A theme unifying the ideas presented in this section is that collaborative activities naturally support social equity values and objectives. Institutions such as franchises, foresight councils, and the Coordination Service can support collaboration among participants in the new electric industry, which in turn would allow consideration of the allocation of costs and benefits among participants, and satisfaction of the other social equity objectives. Siting marketplaces can foster increased public participation in siting decisions and provides mechanisms for sharing the costs and benefits of the siting decisions. The minimum service standards and associated economic regulations, and the integrated social services program all can act to ensure an equitable sharing of costs and benefits, and to protect human welfare. The collaborative electricity 
Table 9. Relationships between values/objectives of Section 2.0 and ideas presented in Section 4.0

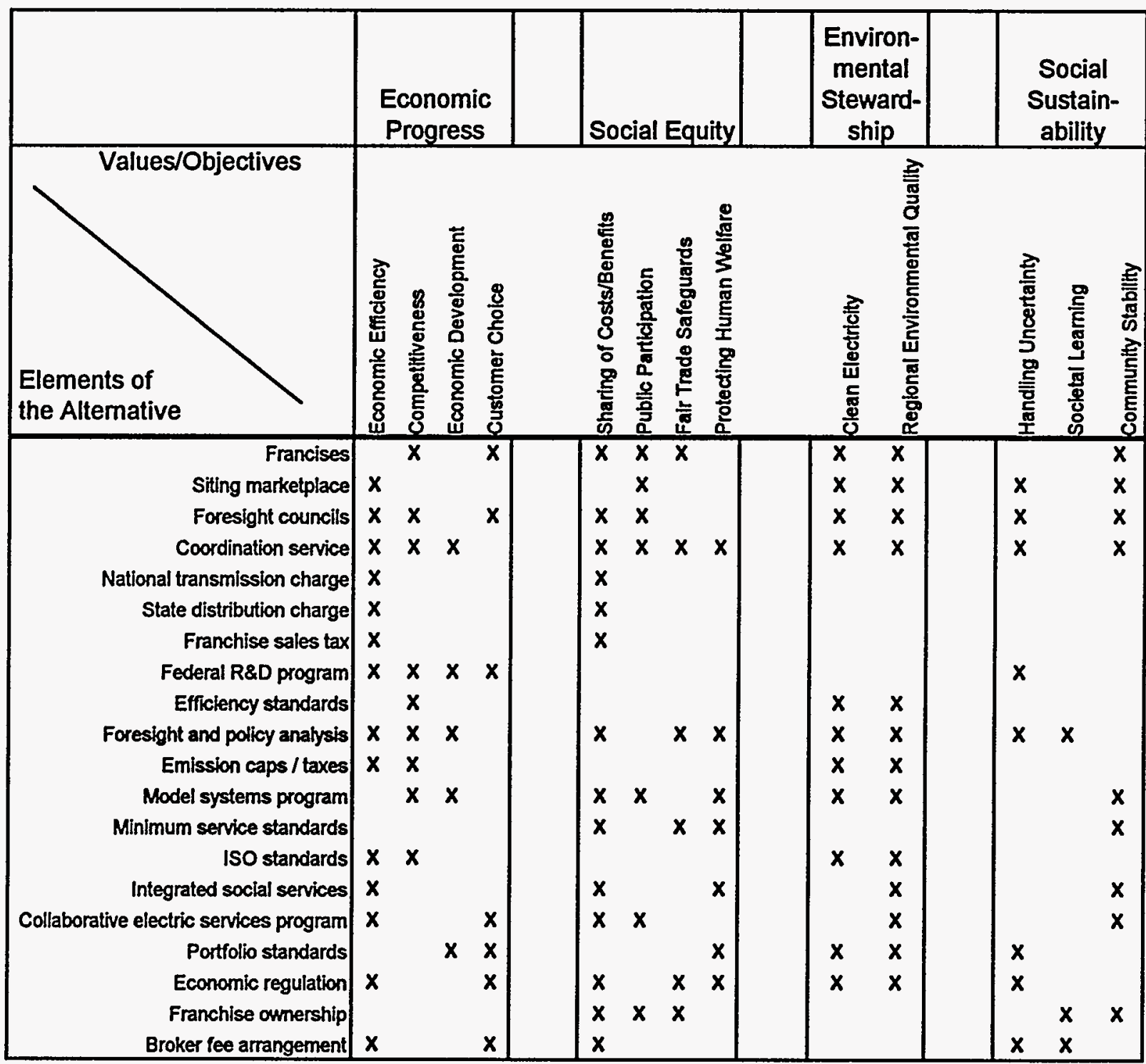

services program would offer an opportunity for low income households and others to offer their time and effort in exchange for electricity services. The Model Systems Program would offer an opportunity to design innovative electricity service systems to improve quality of life and human welfare. There are several approaches to make the financing plan progressive, which would support equity goals. A strong foresight and policy analysis program can ensure that important social trends are identified and that decision makers and the public have the best information possible to make social equity decisions. 
Environmental Stewardship. Environmental stewardship values and objectives can be supported in numerous manners. Having direct impacts on reducing emissions of pollutants are efficiency standards, emission caps and taxes, and portfolio standards. Environmental protection measures can be interwoven into the integrated social services program (i.e., weatherization programs) and the collaborative electricity services program (e.g., operation and maintenance of small scale renewable technologies). Industry adopted ISO standards can also be directly related to environmental protection. Federally-funded R\&D and the Model Systems Program can act to ensure that new technologies are developed and demonstrated. Institutions such as franchises, siting marketplaces, foresight councils, and the Coordination Service can ensure that environmental issues have an opportunity to be thoroughly reviewed. A strong foresight and policy analysis program can ensure that important environmental trends are identified and that environmental decision makers and the public receive the information needed to make wise decisions about the environment.

Social Sustainability. The ideas presented above can support the overarching value of social sustainability and three objectives associated with this value. The objective of making prudent and wise decisions under uncertainty can be supported by siting marketplaces, foresight councils, and the Coordination Service. A strong foresight and policy analysis program also can support this objective as well as providing an institution for society to learn from its past decisions. Portfolio standards and the federal R\&D program can act to reduce uncertainty related to sudden and dramatic changes in fuel prices, fuel availability, and reactions to new knowledge about the global environment. The broker fee arrangement can act to spread risk throughout the industry. Community stability can be fostered through collaborative institutions such as the franchises, siting marketplaces, and Coordination Service. The Model Systems Program can address comprehensive community and energy use designs to promote community stability. Better delivery of better services can also benefit communities. The franchise ownership and decision making structure is also designed to create a community process and spirit.

Overall, the approach keeps to what markets and government do well and generally avoid what they don't do well. For example, explicit comprehensive government-led planning is not part of this approach. Instead, foresight councils and other collaborative institutions are proposed to engender the cooperation needed for a successful industry. On the other hand, the taxes proposed are straightforward to collect, the programs to be implemented have widespread precedent, and no other unusual regulations are proposed. Even the Coordination Service has precedent in the Federal Labor Relations Board. Industry is allowed to provide any services, marketed through brokers and a new market is posited, the siting marketplace. A federal R\&D program will complement industry $R \& D$ to create an industry $R \& D$ program that encompasses both the longterm and the short-term.

As a final point, the elements of this approach do not preclude more traditional actions that have characterized the utility-based industry of the past. For example, franchises can decide to purchase DSM and PUCs can impose DSM standards on franchises as well. Renewable energy should be a major element of the 
federal R\&D program and should be mandated through portfolio standards. Low income programs can be pursued separately by local political jurisdictions, but an integrated approach holds a high potential to make social service delivery more efficient and response to recipient needs.

\subsection{Major Barriers and Other Observations}

There are numerous barriers to implementation of many of the ideas introduced above. There are a number of new ideas that would naturally receive critical review. There are a number of requirements for political jurisdictions to work more closely together, which can be quite challenging. There are a number of new institutions and programs, which will lead to questions about cost and additional bureaucratic problems. All of these issue have merit but may not be as serious as may seem at first glance.

With respect to cost, several provisions are designed to reduce cost and increase efficiency, such as the Coordination Service, siting marketplaces, the integrated social services program, and the collaborative electric services program. Many provisions are already part of the cost structure of providing electric services, such as R\&D, minimum service standards, and supporting regulatory and policy analysis and foresight activities. One major new program, the Model Services Program, provides for cost sharing opportunities among federal, state, and local governments, the franchises, and the private sector.

With respect to institutions, electronic analogues of siting marketplaces are currently being built to host electricity marketplaces (Public Utilities Fortnightly 1995), numerous industry associations already accomplish some of the goals of the foresight councils, and mediation/arbitration organizations have a long history in government. Probably the most controversial institutional recommendation is the franchises, which can be seen as reducing customer choice. As discussed in Sect. 4.2, we think the benefits of franchises outweigh the costs.

Concern and skepticism can be expressed that five new institutions are recommended above. Given the general anti-government mood of the country, this is a legitimate point and needs to be addressed. The first defense is that the five institutions can be implemented individually or in any combination. They all do not need to be implemented at the same time, although possibilities for positive feedbacks among them are significant. Second, none of the institutions are envisioned to be large or excessively bureaucratic. Franchise management can be kept lean as can the management of foresight councils, RBDs, and the Coordination Service. Third, only one proposed new institution actually falls within traditional definitions of 'government', that being the RBDs. Given that franchises are to be customer-owned, it may not be appropriate to consider them as part of government. Siting marketplaces, foresight councils, and the Coordination Service may be managed by government agencies but are designed to facilitate human relationships, not dictate human behaviors. Again, it needs to be emphasized that new institutions for guiding human behavior do not have to rely on legal powers to achieve their goals as long as other incentives and design features are in place. 
Fourth, the institutions in part replace other institutional arrangements and in part capitalize on on-going trends within society (see Table 10). Fifth, few new laws would be needed to implement the institutions. State-level legislation would be needed to implement franchises, the universal distribution charge, and possibly the RBDs. A national law would be needed to implement a national transmission tax. Other ideas such as the foresight councils, siting marketplaces, the Coordination Service, and many of the programs listed in Table 8 can be carried about under existing legislation by existing institutions.

These defenses of the institutional aspects of the ideas presented above should not be interpreted that implementing any new institution would be easy given any political climate. Indeed, careful thought and strong dedication would be needed for any of the ideas to succeed. On the other hand, new institutions do not automatically inherent perceived shortcomings of many government and even large private sector organizations.

Table 10. Summary of proposed institutions

\begin{tabular}{|c|c|c|c|}
\hline Name & Mission & $\begin{array}{l}\text { Relationship to existing } \\
\text { institutions / processes / } \\
\text { programs }\end{array}$ & New responsibilities \\
\hline $\begin{array}{l}\text { Regional Board of } \\
\text { Directors }\end{array}$ & $\begin{array}{l}\text { Administer regional } \\
\text { electricity organizations } \\
\text { and set policy for regional } \\
\text { electricity issues }\end{array}$ & $\begin{array}{l}\text { Involves existing PUCs and } \\
\text { formalizes existing trends toward } \\
\text { regional cooperation }\end{array}$ & $\begin{array}{l}\text { Oversight of new system } \\
\text { operation and transmission } \\
\text { organizations and several } \\
\text { new institutions }\end{array}$ \\
\hline Franchises & $\begin{array}{l}\text { Purchase electricity } \\
\text { services for franchise } \\
\text { members }\end{array}$ & $\begin{array}{l}\text { Traditional responsibilities shift } \\
\text { from "utilities" to franchises }\end{array}$ & $\begin{array}{l}\text { Participating in } \\
\text { marketplaces }\end{array}$ \\
\hline Siting marketplaces & $\begin{array}{l}\text { Assist in the siting of } \\
\text { generation and } \\
\text { transmission facilities }\end{array}$ & $\begin{array}{l}\text { Extends trends related to } \\
\text { electronic marketplaces and } \\
\text { electronic democracy }\end{array}$ & N/A \\
\hline Foresight Councils & $\begin{array}{l}\text { Identify important electric } \\
\text { industry trends and threats } \\
\text { and propose appropriate } \\
\text { responses }\end{array}$ & Partially replaces IRP & None \\
\hline $\begin{array}{l}\text { Coordination } \\
\text { Service }\end{array}$ & $\begin{array}{l}\text { Apply alternative dispute } \\
\text { resolution techniques and } \\
\text { engender collaborations } \\
\text { and conflict avoidance }\end{array}$ & Partially replaces IRP & $\begin{array}{l}\text { Alternative dispute } \\
\text { resolution, collaborative } \\
\text { activities }\end{array}$ \\
\hline
\end{tabular}




\subsection{CONCLUDING REMARKS}

This is a time for debate and discussion, introspection and experimentation, stress and opportunity for the U.S. electric industry. A fascinating observation about restructuring is that discussions, values, and transition plans widely differ across the states. Some states are moving aggressively toward full-retail competition and are being driven primarily by economic goals. Other states are considering restructuring but are more influenced by other values, such as social equity and environmental stewardship. Even yet another group of states is only beginning to discuss restructuring. In all of these cases and more, state regulators and other people involved in the discussions face complex issues and difficult trade-offs.

To better understand what difficult trade-offs are facing the decision makers, this report explores key actions that would be undertaken by industry players and by government if driven primarily by one of the four overarching values shown in Table 1. For example, in a situation driven mainly by economic values, restructuring plans would target the achievement of economic objectives such as increasing production efficiency and industrial competitiveness. However, in such a situation, it is also likely that many actions that have been traditionally pursued by the electric industry would go undone. Such actions include much longterm public interest research (e.g., on human health and global climate change), much energy efficiency, much renewable energy, and low income programs. In a situation driven by social equity concerns, restructuring plans would most likely be quite different, with actions such as long-term portfolio and risk management and low income programs being emphasized at the expense of some other objectives. In a situation driven by environmental stewardship concerns, energy efficiency, renewable energy and pollution reduction programs would be emphasized with support for some social programs being traded-off. Lastly, in a situation driven by social sustainability concerns, long-term research and portfolio and risk management would be emphasized, possibly at the expense of some consumer-protection and low-income programs. Tables 11 and 12 summarize these trade-offs.

Explicitly describing such trade-offs is useful for several reasons. First, the exercise helps to clarify the values underlying restructuring debates and the likely results of pursuing each one separately. Second, it explains the enormous inertia to change in the electric industry. Third, it indicates that it will be virtually impossible to fully meet all key objectives without explicitly accepting and pursuing multiple values. And finally, it suggests that it will be difficult if not impossible to satisfy all four overarching values within a context that overlays retail competition upon an institutional structure best suited to regulate verticallyintegrated electric utility monopolies.

Acting on this observation, a set of new ideas for institutions, programs, and financing mechanisms are introduced in the fourth section of this report. Five institutional innovations are proposed. The RBD is a multi-state institution that has the major responsibility for overseeing system service and transmission service 
Table 11. Key actions associated with different values

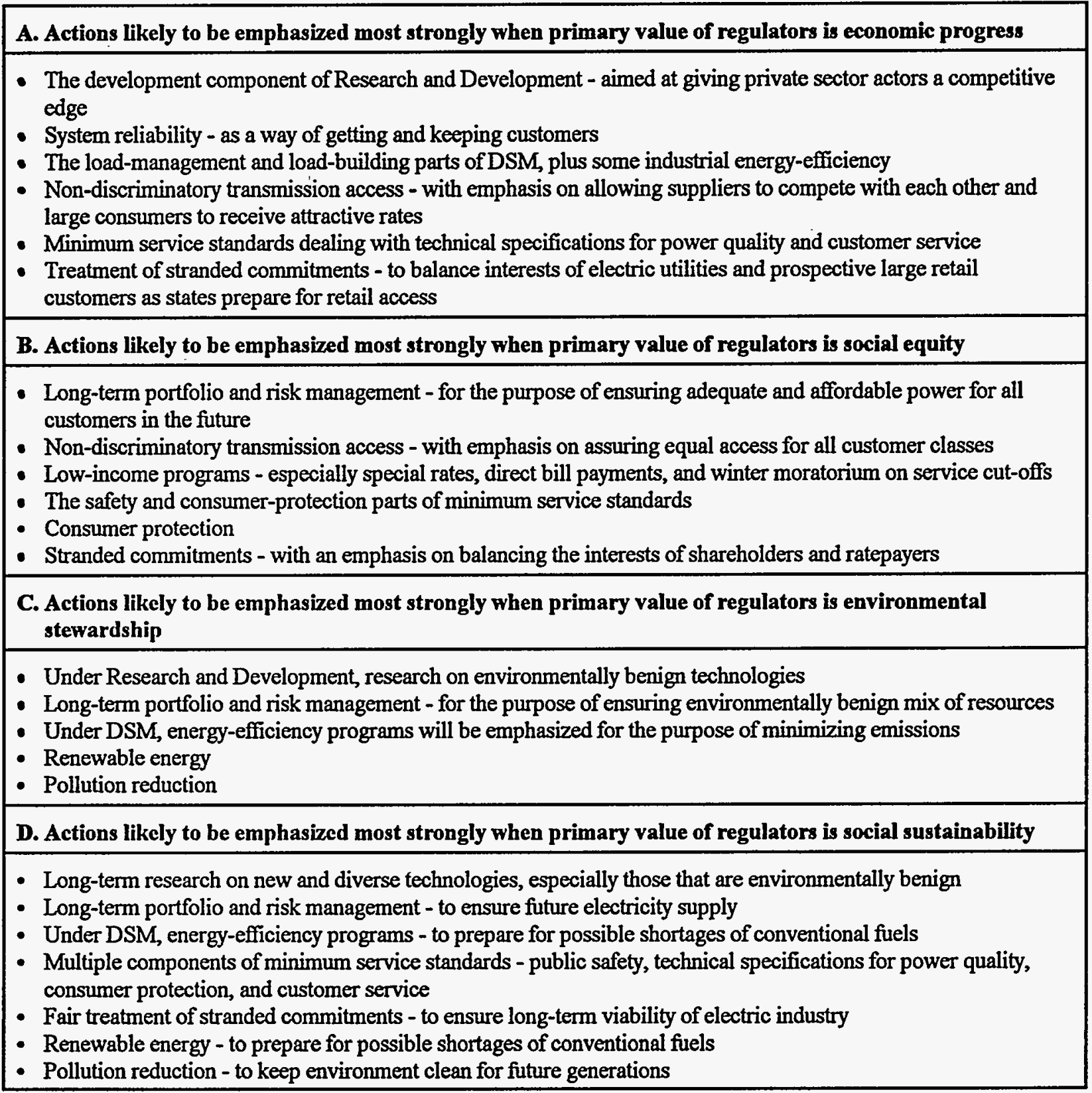


Table 12. Trade-offs associated with each single-value approach

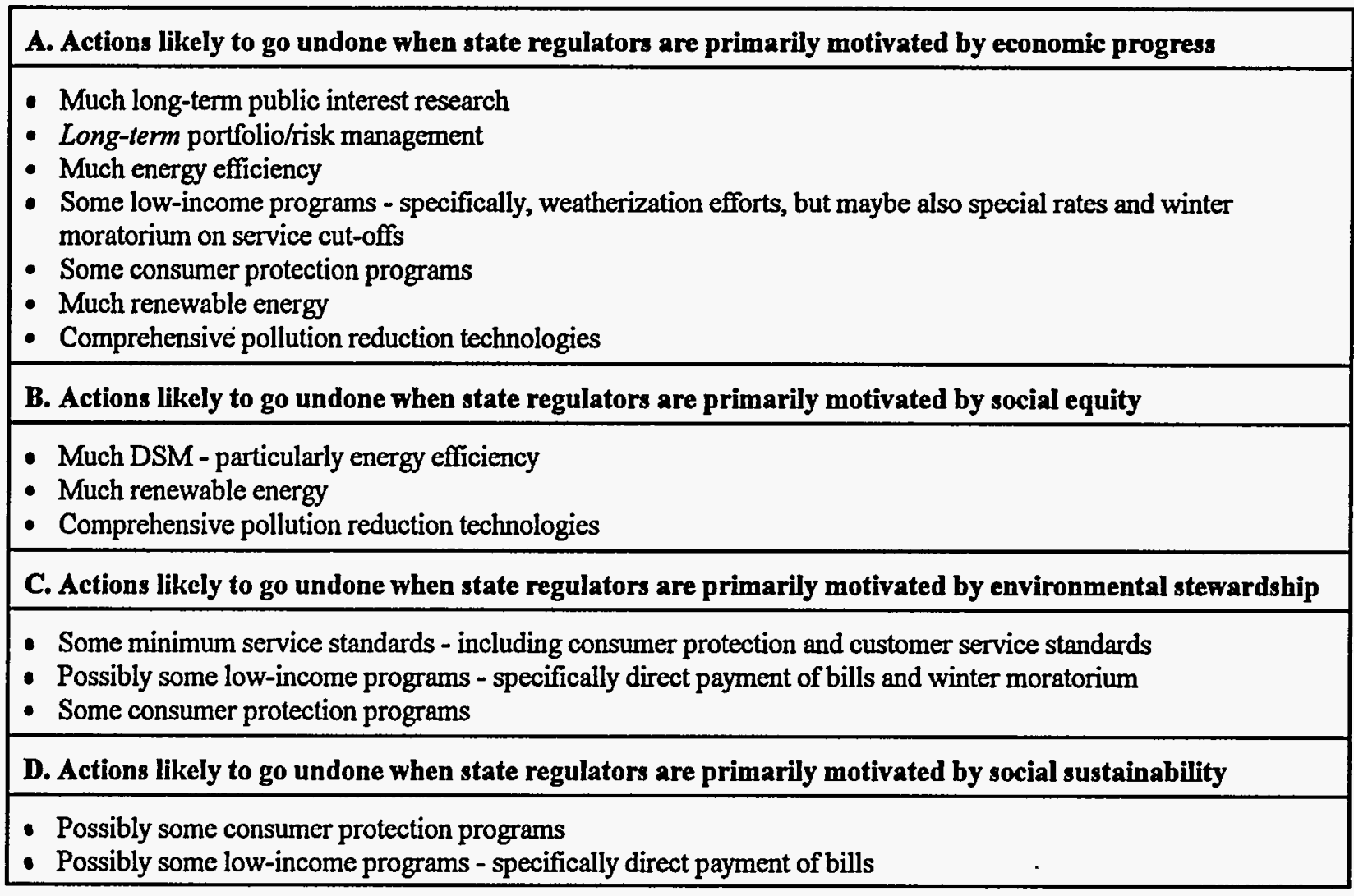

organizations. Customer-owned franchises are awarded by state PUCs either along geographic or user-class criteria and have the responsibility for negotiating electricity service contracts with power brokers and implementing franchise-level government directives (such as portfolio standards). Electricity facility siting marketplaces are designed to foster communication among communities to arrive at financially-attractive packages related to the location of new electric generation facilities, such as generation plants and transmission lines. Electric industry foresight councils are charged with discussing the future of the industry, identifying risks and threats to the industry, and arriving at general, systemic responses to the threats. The Electric Industry Coordination Service has the responsibility for alternative dispute resolution and for proactively seeking to foster positive collaborations among industry players and the various governments.

It is recommended that government foster and have responsibility for several activities. The government should maintain a long-term, high-risk, high-payoff energy-sector research and development program. Built on this activity would be a more applied Model Systems Program, which would feature the design, development and field demonstration of information-technology based systems that can provide a plethora of services. Tied to this program would be a program to integrate the provision of energy services, possibly with other closely tied social services such as housing. The potential for innovation in providing energy and social 
services is great. For example, ways to have service recipients collaborate with government in the provision of such services should be pursued. The government also needs to ensure that minimum service standards are set and met.

With respect to environmental and resource conservation issues, it is recommended that the government continue energy efficiency and emission cap/tax programs, institute portfolio standards at the franchise level, and work with the industry to adopt ISO standards related to environmental and product quality. To assist in the design and implementation of all these programs, the government needs to conduct high quality, unbiased foresight and policy analyses.

With respect to financing, it is recommended that a national transmission (wires) charge, state-level universal distribution charge or all-fuels tax, and franchise-level sales tax be adopted. Low income subsidies and/or graduated electricity rates can be instituted to make this taxing regime more progressive.

In combination, these ideas work to satisfy all four overarching values and associated objectives. With respect to economic progress, retail competition is preserved, the financial regime is based on electricity use, the environmental protection provisions are largely based on market principles, and many of the proposed government programs are intended to provide better services at lower cost. With respect to social equity, franchises provide a mechanism to foster fairness and participation, as does the Coordination Service and other government programs. Environmental stewardship is fostered by siting marketplaces, foresight councils and the mix of environmental protection mechanisms, from emission caps to portfolio and energy efficiency standards. Social sustainability is promoted through foresight activities and the social stability provided by franchises, the Coordination Service, and better provision of energy and social services.

Many issues require additional consideration. For example, what are the guidelines for creating and managing RBDs? Should franchises be customer-owned, government-owned, or incorporated as aggregators? Who should be allowed to make commitments in a siting marketplace and at what point are such commitments legally binding? Should industry players be required to participate in foresight councils? Exactly what energy service programs can be integrated? How should the national transmission charge, distribution charges, and franchise taxes be determined? There is no lack of important and challenging issues related to restructuring and meeting public policy responsibilities.

It is clear to us that it will be difficult if not virtually impossible to satisfy the overarching values of economic progress, social equity, environmental stewardship, and social sustainability by overlaying retail competition over an institutional framework developed to oversee and regulate the vertically-integrated monopoly-based utility-dominated electric power industry of the past. As shown in Section 3, profound trade-offs will need to be made which strike at those values which are most dearly held by citizens and electricity consumers alike. 
On the other hand, as shown in Section 4, through institutional innovation and a great deal of hard work, approaches are possible that can indeed simultaneously satisfy all four overarching values.

As a final point, many of the ideas and problems presented herein can be expanded to encompass aspects of society and the economy that extend beyond the immediate concerns of the electric power industry. Each of the institutional recommendations can be expanded to include environmental concerns, for instance. Siting marketplaces can be used to discuss the siting of new prisons as well as new toxic waste incinerators and power generating facilities. Foresight councils can consider the profusion of global and national economic, political, social, technological, and environmental trends affecting society, many of which do indeed impact the electricity industry (see Tonn and Schaffhauser 1994). New regional institutions may be necessary to deal with multi-jurisdictional environmental and infrastructure problems, in addition to electric industry problems. From an even broader perspective, the debates now taking place in the electric industry are a microcosm of fundamental debates that have engaged Americans since the founding of the nation. How to balance individualism and communitarianism, both of which have a place in American society, is extraordinarily complex. As this report shows, difficult tradeoffs await today's decision makers, as those in the past have faced. The report also communicates that there are always opportunities to pursue new ideas to better achieve balance in satisfying the multitude of important social values and objectives. 



\subsection{NOTES}

1. This excellent idea was suggested during the Dec. 5, 1995 meeting in Washington, DC that was convened to discuss the first draft of this report.

2. We believe that the franchise idea has relationships to other ideas presented in the restructuring debate. For example, franchises could help achieve some of the community aggregation goals put forth by Heitz and Harvey (1995).

3. There are many ways that franchise ownership and management can be structured. Here is one example. Membership in a franchise is open to any electricity-bill paying customer. Members elect a franchise Board of Directors. The Chairperson of the Board is empowered to sign contracts on behalf of the franchise. The main responsibility of the Board is to fashion contractual alternatives for consideration by a subset of the franchise membership, called the Decision Making Council. The main responsibility of the Council is to vote on contractual alternatives presented by the Board. It is recommended that between $1 \%$ and $10 \%$ of the franchise members be appointed to the Council. To be appointed, a franchise member needs the support of some pre-specified number of other franchise members, who can only support one member for the Council. For example, if there are 1000 franchise members, and the goal is to have $10 \%$ of the members in the Council, then each Council member would need the support of 9 other franchise members. This ownership and organizational structure promotes membership participation, and allocates power throughout the franchise, yet allows for the fact that many members may be unable, for whatever reason, to become as involved in these types of decisions as one may hope.

This is obviously a very simplified presentation of an innovative approach to franchise ownership and organizational structure. Numerous issue require extended evaluation. For example, is it better to allow a range of commitments (e.g., for the example, maybe 8-12), how do members make commitments, how commitments are tracked, and can commitments be changed at any time? The point is that there are many potentially new institutional forms that could potentially be proposed and evaluated as restructuring progresses.

4. One potential concern with allowing non-spatially defined franchises has to do with electricity use metering. For example, non-real time meters cannot indicate how much electricity was consumed by a customer during peak hours. Extended over a large and spatially noncongruous customer base, it would be very difficult to determine what contribution to peak demand emanated from any franchise. This problem may disappear in the mid-term, though, as real-time metering technology becomes cost effective and commonplace. 
5. Our own opinion is that states and localities, on balance, will not want these facilities. We base this opinion what is happening in the area of hazardous waste. Basically, states do not want to host new hazardous waste facilities, be they landfills or incinerators. The relatively small number of new jobs does not outweigh the perceived health and environmental disbenefits. The result is that states that do not have such facilities ship their hazardous wastes to states that do possess such facilities, which causes severe political problems if the receiving states begin to perceive themselves as dumping grounds for the have-not states. Given a choice, states will not want to host new, large generation plants, especially if they already are having trouble meeting air quality standards. However, communities may volunteer to host the facilities if others

6. The idea for Electric Industry Foresight Councils can be traced to numerous trends and other ideas. For example, the concept of foresight is gaining prominence in the business community in the area of strategic planning. Also, the United Nations, along with the U.S. Environmental Protection Agency, is sponsoring a the Millennium Project, whose goal is to create an international cyberspace network of environmental experts to conduct foresight activities into potential future environmental problems.

7. With respect to relationships between the Councils and the Service, it might be beneficial to designate branches of the Service that have responsibilities for the same areas as covered by state and regional Councils. In this way, these regional Service branches could be better overseen by the RBDs. It necessary nevertheless to implement the Service in such a way so that inter-regional and national issues can be identified, evaluation, and resolved.

8. The R\&D issue is much more complex and deserves much more attention than it can be given in this report. An assessment of how specifically the industry's research profile may change and how the federal government should specifically respond is needed. 


\subsection{ACKNOWLEDGMENTS}

We thank Eric Hirst for his comments on the initial rough draft of this report. We also thank the following people who attended a meeting on December 5th, 1995, in Washington, DC, to discuss the first draft of this report: Doug Bauer, Rich Cowart, Jeff Gleason, Chuck Guinn, Cheryl Harrington, Eric Hirst, Henry Lee, Gordon McDonald, David Meyer, Elizabeth Stipnieks, and Mary Beth Tighe. Jan Hamrin, Jim Gallaghar, William Miller, Mark Thornsjo, Dennis Ray, and Martin Kushler also provided valuable comments on the draft report.

We also thank Sheila Moore for her invaluable assistance in organizing the December 5 th meeting and in preparing this report. 


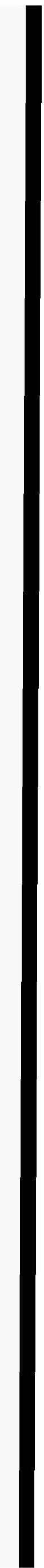




\subsection{REFERENCES}

R. N. Bellah, R. Madsen, W. Sullivan, A. Swidler, and S. Tipton 1992. The Good Society, Vintage Books, New York, NY.

J. Coughlin 1995. “Alternative Dispute Resolution in Electricity: Just Do It!” The Electricity Journal, November, 68-75.

L. Cullen, G. Mathis, D. Ray, and R. Stevenson 1994. Policy Options for Competition in Wisconsin's Electric Power Industry, Wisconsin Public Utility Institute, University of Wisconsin, Madison, WI, September.

Electricity Consumers Resource Council 1994. "Comments of the Electricity Consumers Resource Council Before the Public Utilities Commission of the State of California," June 23, 1994.

J. Hamrin, W. Marcus, F. Morse, and C. Weinberg 1994. Affected with the Public Interest: Electric Utility Restructuring in an Era of Competition. National Association for Regulatory Utility Commissioners, Washington, DC, September.

E. Heitz and H. Harvey 1995. Utility Industry Restructuring: New Levers for Sustainable Energy in the Great Utility Debate: A Briefing for Foundations, The Energy Foundation, San Francisco, CA, October 2.

L. Hill 1995. A Primer on Incentive Regulation for Electric Utilities, ORNL/CON-422, Oak Ridge National Laboratory, Oak Ridge, TN, October.

E. Hirst, B. Tonn, and D. Bauer 1995. “The Future of IRP," The Electricity Journal, 8(3), 74-84.

New York Public Service Commission 1994. "Opinion and Order Regarding Proposed Principles to Guide the Transition to Competition," Opinion No. 94-27, Case 94-E-0952 - In the Matter of Competitive Opportunities Regarding Electric Service, December 22.

Public Utilities Commission of the State of California 1994. Interim Opinion: Procedural Schedule, Call for Briefs, and Applicability of CEQA, December 7, 10.

Public Utilities Fortnightly, 1995. “Information Technology: Real-time Networks: A Peek at Tomorrow's Transmission Market," 133 (18), 29-36. 
P. Senge 1990. The Fifth Discipline: The Art \& Practice of the Learning Organization, Doubleday, New York.

S. Tierney 1994. "Comments of the United States Department of Energy," Testimony before the Public Utilities Commission of the State of California, Docket No. R. 94-04-031, June 8. Also, see Robert Nordhaus and Mary Nichols 1994. "Proposed Principles Submitted by the United States Department of Energy and the U.S. Environmental Protection Agency" Case 93-M-0229, State of New York Public Service Commission, Sept.

B. Tonn, E. Hirst and D. Bauer 1995. Public-Policy Responsibilities in a Restructured Electricity Industry. ORNL/CON-420, Oak Ridge National Laboraory, Oak Ridge, TN, June.

B. Tonn and D. White 1996. "Sustainable Societies in the Information Age," The American Sociologist, 27(1), 102-121.

B. Tonn and A. Schaffhauser 1994. Perspectives on the Future of the Electric Utility Industry. ORNL/CON-385, Oak Ridge National Laboraory, Oak Ridge, TN, April. 


\section{INTERNAL DISTRIBUTION}

1. D. Bauer

2. L. Baxter

3. L. Berry

4. D. S. Bjornstad

5. R. Braid

6. M. A. Brown

7. F. C. Chen

8. J. Christian

9. G. Courville

10. P. D. Fairchild

11. S. Hadley

12. S. G. Hildebrand

13. L. J. Hill

14. E. Hillsman

15. E. Hirst

16. P. J. Hughes

17. C. R. Kerley

18. B. Kirby

19. R. Lee
20. P. Leiby

21. J. M. MacDonald

22. V. C. Mei

23. D. E. Reichle

24. D. T. Rizy

25. A. C. Schaffhauser

26. M. Schweitzer

27. R. B. Shelton

28. J. Tomlinson

29. J. Van Dyke

30. J. VanCoevering

31. D. L. White

32. T. J. Wilbanks

33. ORNL Patent Office

34. Central Research Office

35. Document Reference Section

36. Laboratory Records (RC)

37-38. Laboratory Records Dept.

\section{EXTERNAL DISTRIBUTION}

39. Dr. Thomas E. Drabek, Professor, Department of Sociology, University of Denver, Denver, Colorado 80208-0209.

40. Mr. George F. Sowers, P. E., Senior Vice President, Law Companies Group, Inc., 114 Townpark Drive, Suite 250, Kennesaw, Georgia 30144-5599.

41. Dr. C. Michael Walton, Ernest H. Cockrell Centennial Chair in Engineering and Chairman, Department of Civil Engineering, University of Texas at Austin, Austin, Texas 78712-1076

42-43. OSTI, U. S. Department of Energy, P. O. Box 62, Oak Ridge, Tennessee 37831.

44. ORNL Site Manager, U.S. Department of Energy, Oak Ridge National Laboratory, P. O. Box 2008, Oak Ridge, TN 37831-6269.

45-350. External Energy Efficiency and Renewables Section Distribution Mailing List and extra copies to $S$. A. Moore, 4500 N, G-32. 


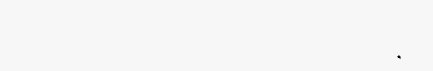

